\title{
DA ILHA DE SÃO JOSÉ AO ASSENTAMENTO MIRINDIBA: A GEOGRAFIA DA LUTA CAMPONESA A PARTIR DA IMPLANTAÇÃO DA USINA HIDRELÉTRICA DE ESTREITO ${ }^{1}$
}

\section{FROM THE ISLAND OF SÃO JOSÉ TO THE MIRINDIBA SETTLEMENT: THE GEOGRAPHY OF THE CAMPONESE FIGHT FROM THE IMPLEMENTATION OF THE ESTREITO HYDROELECTRIC PLANT}

\author{
Delismar Palmeira COSTA ${ }^{2}$ \\ Elizeu Ribeiro LIRA ${ }^{3}$
}

\begin{abstract}
Resumo: Esse artigo tem por finalidade analisar a luta pela continuidade do modo de vida camponês, tomando por base a trajetória de famílias expulsas da Ilha de São José, em Babaçulândia (TO), como consequência da implantação da Usina Hidrelétrica de Estreito (MA). Na Ilha de São José habitavam mais de 70 famílias que foram banidas de suas terras - hoje, completamente submersas pelas águas do reservatório da usina. Desse montante, 18 unidades produtivas vieram a formar o assentamento Mirindiba, localizado em Araguaína (TO), município vizinho a Babaçulândia. Tal assentamento foi criado pelo Consórcio Estreito Energia (CESTE), responsável pela construção da hidrelétrica. Nesse novo território, inúmeras dificuldades são enfrentadas pelas famílias, o que não as impede, entretanto, de lutar constantemente pela reprodução do seu modo de vida.
\end{abstract}

Palavras-Chaves: Continuidade; Modo de vida camponês; Ilha de São José; Usina Hidrelétrica de Estreito; Assentamento Mirindiba.

\begin{abstract}
This article aims to analyze the struggle for continuity of the peasant way of life, based on the trajectory of displaced families in the Island of St. Joseph in Babaçulândia (TO) as a result of the implementation of the Estreito Hydroelectric Power Plant (MA). On the island of São José, there were more than 70 families that were banished from their lands - today, completely submerged by the waters of the plant's reservoir. Of this amount, 18 production units came to form the Mirindiba settlement, located in Araguaína (TO), a neighbor municipality from Babaúdândia. This settlement was established by the Estreito Energia Consortium (CESTE), responsible for the construction of the dam. In this new territory, countless difficulties are faced by families, which does not prevent them from constantly fighting for the reproduction of their way of life.
\end{abstract}

Keywords: Continuity; Peasant way of life; São José Island; Estreito’s Hydroelectric Plant; Mirindiba Settlement.

\footnotetext{
${ }^{1}$ Esse texto faz parte dos resultados apresentados na dissertação de mestrado intitulada: Os Camponeses da Ilha de José e a Implantação da Usina Hidroelétrica de Estreito: da terra de trabalho ao território do devir, defendida por Delismar Palmeira Costa junto ao Programa de Pós-Graduação em Geografia da Universidade Federal do Tocantins, sob a orientação do professor Dr. Elizeu Ribeiro Lira, no ano de 2019.

${ }^{2}$ Doutorando em Geografia pela Universidade Federal de Goiás (UFG). E-mail delismarcosta@ gmail.com

${ }^{3}$ Professor Doutor do Programa de Pós-Graduação em Geografia da Universidade Federal do Tocantins (PPGG-

UFT). E-mail. liraelizeu@mail.uft.edu.br
} 


\section{Introdução}

Os grandes empreendimentos hidro energéticos vêm causando impactos ambientais e sociais em escala cada vez mais ampliada no Brasil. Nesse contexto, um sem números de sujeitos sociais passam de moradores à atingidos em um curto espaço de tempo. A Usina Hidrelétrica de Estreito (UHE Estreito) não foge a essa regra. Esse empreendimento está localizado no médio curso do rio Tocantins, mais precisamente na divisa dos estados do Tocantins e do Maranhão, entre os municípios de Estreito (MA) e Aguiarnópolis (TO).O seu reservatório atingiu diretamente um total de 12 municípios: Estreito e Carolina, no Maranhão; Aguiarnópolis, Babaçulândia, Barra do Ouro, Darcinópolis, Filadélfia, Goiatins, Itapiratins, Palmeirante, Palmeiras e Tupiratins, no Tocantins.

A UHE Estreito foi construída durante toda a primeira década desse século, sendo oficialmente inaugurada em 2012, atingindo mais de 5000 famílias, de acordo com o Movimento dos Atingidos por Barragens (MAB). Camponeses, barqueiros, comerciantes, pescadores, indígenas e etc. tiveram os seus modos de vida esfacelados após a implantação desse empreendimento. A expulsão desses grupos sociais de suas antigas moradas é uma questão inerente à dinâmica espacial do capital promovida pelos atores da hidroenergia. $\mathrm{O}$ "recomeço" desses sujeitos está antagonicamente ligado aos interesses das grandes empresas. Os ressarcimentos não cobrem os prejuízos causados por essas corporações, que acabam por açambarcar a riqueza das comunidades tradicionais. As firmas hegemônicas partem da premissa de que estão se expandindo em direção a "espaços vazio",e com o amparo do Estado e de toda a superestrutura jurídico-política, conseguem atribuir um valor irrisório aos recursos existentes nos territórios das populações atingidas.

A busca pela compreensão desse processo de desconfiguração espacial se torna crucial à Geografia, sobretudo pela questão socioambiental desencadeada por esses empreendimentos. As populações camponesas quase sempre são obrigadas a migrar para regiões distantes de seus territórios originais. A ciência geográfica, enquanto disciplina que estuda a análise das formas de organização do espaço, deve se ater a essas problemáticas por dois motivos principais: primeiro, por se tratar de uma forma de produção e (re) organização do espaço; segundo, por envolver interesses antagônicos entre classes sociais, que refletirão imediatamente no comportamento e ação dos sujeitos, das empresas e das instituições, que são partes integrantes do espaço geográfico. 
Emerge daí a luta dos camponeses atingidos por barragens. A UHE Estreito,como se observará em nossa análise, afetara o cotidiano de inúmeros sujeitos desse segmento. Partindo desses pressupostos, esse texto tem por finalidade analisar a luta pela continuidade do modo de vida camponês, tomando por base a trajetória de famílias expulsas da Ilha de São José, em Babaçulândia (TO), como consequência da implantação da Usina Hidrelétrica de Estreito (MA). Na Ilha de São José habitavam mais de 70 famílias, que foram banidas de suas terras, hoje completamente submersas pelas águas do reservatório da usina. Desse montante, 18 unidades produtivas vieram a formar o assentamento Mirindiba, localizado em Araguaína (TO), município vizinho a Babaçulândia. Tal assentamento foi criado pelo Consórcio Estreito Energia (CESTE), responsável pela construção da hidrelétrica. Nesse novo território, inúmeras dificuldades são enfrentadas pelas famílias, o que não as impede, entretanto, de lutar constantemente pela reprodução do seu modo de vida.

Esse texto está dividido em mais cinco partes além dessa introdução. No primeiro item, é narrado o processo de expulsão dos camponeses da Ilha de São José, e contemplam-se também as formas de organização das famílias na antiga morada, sobretudo as que dizem respeito à produção. Na sequência, é feita uma breve descrição do assentamento Mirindiba, ressaltando os principais aspectos do novo território. Em seguida, são analisadas as formas de luta pela continuidade do modo de vida camponês no assentamento Mirindiba, através de relatos e também de observações empíricas, amparadas nos pressupostos teóricos do marxismo. Por fim, é evidenciada a questão da luta pela propriedade jurídica definitiva das terras, sendo a ausência de títulos retratada como um desestímulo às famílias. Logo após são apresentadas as devidas considerações finais, de acordo com o apanhado geral do que foi problematizado.

\section{Os camponeses da Ilha de São José e o processo de expulsão da terra}

A implantação da UHE Estreito trouxe consigo inúmeros processos migratórios, dentre eles o que diz respeito à expulsão dos camponeses que antes residiam na Ilha de São José (Mapa 1), localizada à montante da barragem e à jusante da sede do município de Babaçulândia. Por ter essa localização, a mesma teve as suas terras completamente inundadas pelas águas do reservatório. Na localidade habitavam mais de 70 famílias, com uma população estimada em mais de 260 pessoas. Todos esses sujeitos foram retirados de seu 
habitat ancestral para que a usina pudesse ter funcionalidade técnica e econômica. Desse montante, um grupo composto por 18 famílias viera a formar o assentamento Mirindiba, em Araguaína, usado como forma de "compensação". Essas unidades produtivas passaram por todo o processo autoritário de desapropriação, comandado pelos empreendedores. Nesse item, serão analisados os principais aspectos desse fato, além de ser apresentado um breve panorama do modo de vida na antiga morada.

Mapa 1 - Localização da Ilha de São José.

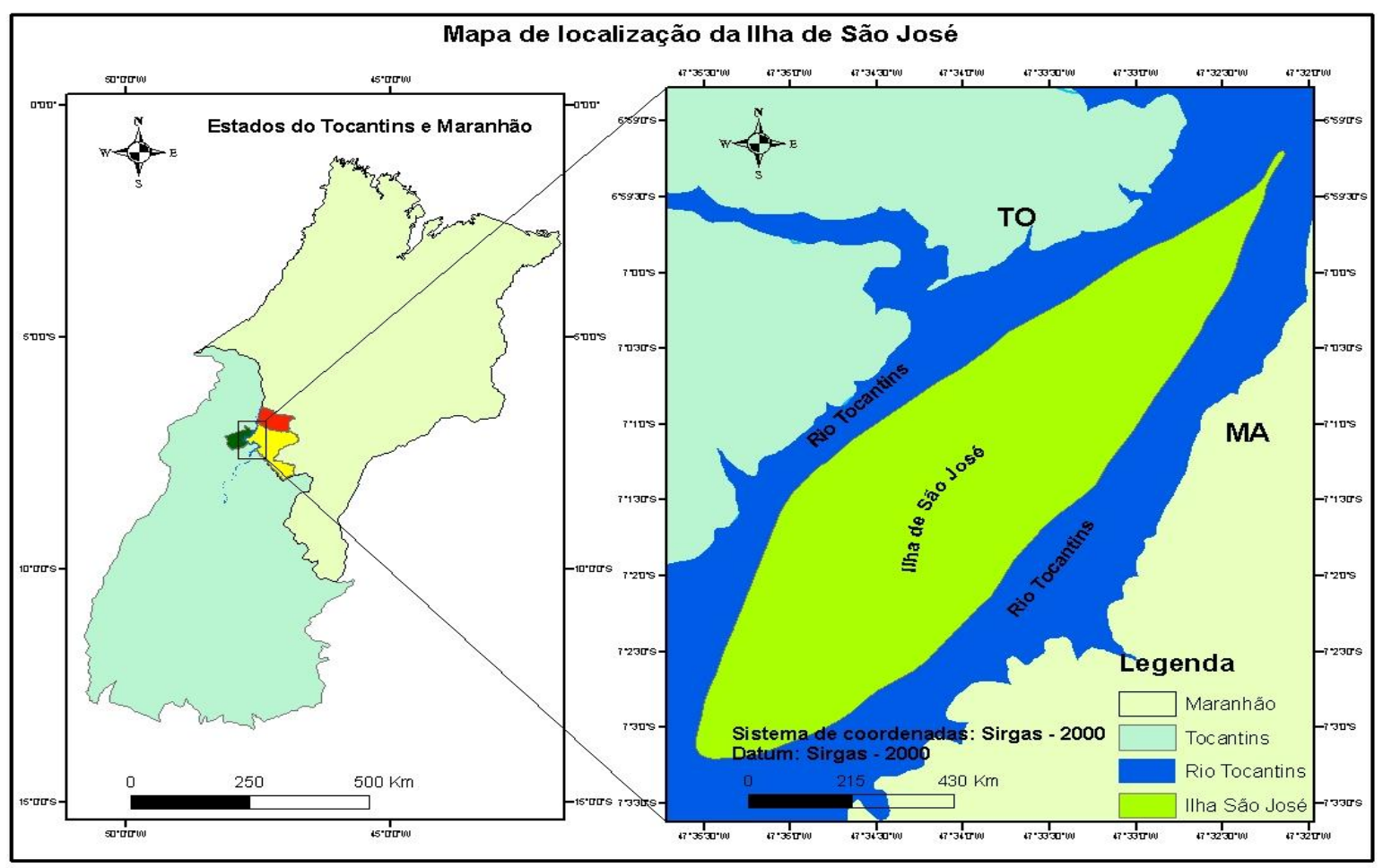

Fonte: SEPLAN-TO. (Organização dos Autores).

Na Ilha de São José, a vida era típica de um campesinato quase que autossuficiente. A sua dependência do mercado era irrisória, já que o volume da produção era satisfatório e diversificado, o que garantia a segurança alimentar em patamares significativos. A agricultura era de tipo tradicional. De quando em vez praticava-se a derrubada e a queimada da vegetação, seguidas da semeadura que desabrochava em plantações, comumente chamadas de roças (Imagem 1$)$.

Tal prática, entretanto, se dava dentro de limites razoáveis, sobretudo pela existência de vazantes às margens do rio Tocantins. Nas vazantes, a fertilidade do solo era renovada ciclicamente pelas cheias do rio, tornando-se o cenário mais adequado à produção de cereais e legumes pelos camponeses. 
Imagem 1 - Agricultura na Ilha de São José.

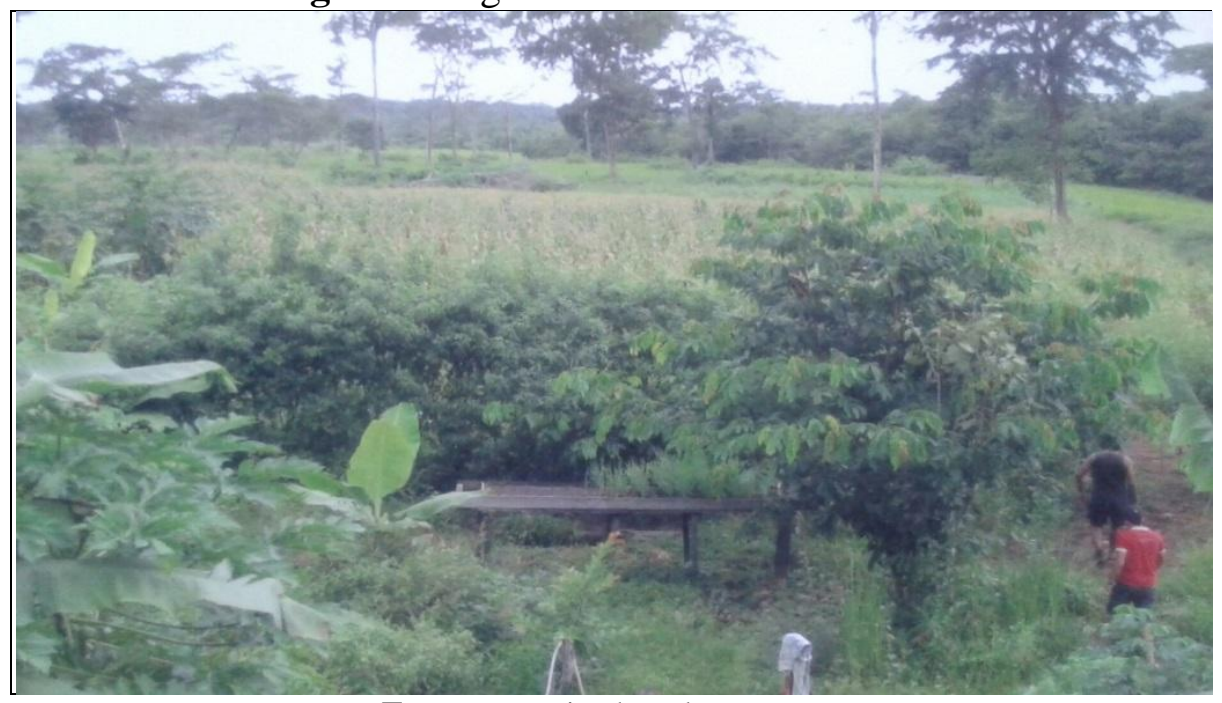

Fonte: organizado pelos autores.

A configuração territorial era composta por sistemas naturais, dotados de grande poder de resiliência. Maria da Ilha (54 anos), forte liderança camponesa diante da implantação da UHE Estreito, faz questão de ressaltar que: "Na ilha, a terra já vinha preparada". As vazantes situavam-se nas partes mais planas, próximas às margens do rio.Durante a fase de cheia, o rio depositava um grande volume de húmus nas terras baixas, aumentando assim a quantidade de matéria orgânica no solo. No período de seca, ou seja, na vazante do rio, a terra submergida era exposta novamente, mostrando-se qualitativamente melhor do que antes. Dando seguimento ao ciclo, os camponeses então realizavam o plantio nessas áreas durante o restante do ano, até que fossem inundadas novamente.

A sabedoria camponesa acumulada ao longo de várias décadas foi transmitida de geração em geração. Os ciclos naturais, de um modo geral, não eram estranhos aos camponeses, muito pelo contrário, quase sempre eram utilizados em benefício da produção. A Ilha de São José era o "território abrigo" dos camponeses que ali habitavam. Não havia interesse em acumular riquezas exorbitantes.A finalidade última da produção era a própria manutenção da vida imediata. Plantava-se o arroz duas vezes por ano (julho-agosto e novembro-dezembro), criando-se assim uma autossuficiência na produção desse artigo, que é base da alimentação camponesa.

Quando se fazia necessária à utilização de qualquer sistema técnico, nada impedia, entretanto, que a sua eficácia estivesse condicionada aos atributos naturais da ilha. O emprego de irrigação no período de estiagem, por exemplo, baseava-se no escoamento da água de riachos localizados nas partes mais altas. De acordo com Gerdean Carvalho (40 anos), camponês criado na Ilha de São José, nesse sistema de irrigação era utilizado "apenas a 
encanação, a água vinha por gravidade, não precisava de bomba e nem de pagar nada por isso". A produtividade do trabalho era tamanha que, segundo os entrevistados, faltavam utensílios e depósitos para a estocagem das safras. Plantava-se de tudo um pouco, mas os principais artigos eram a abóbora, o arroz, o milho, a mandioca e o feijão, este era de longe o produto de maior destaque. A leguminosa era plantada preferencialmente em abril, quase no encerramento do período chuvoso, sendo a colheita realizada nos meses de julho e agosto.

A vegetação era típica de Cerrado, com variações do tipo Mata de cocais. O Babaçu, palmácea endêmica da região (Imagem 2), representava a espécie mais significativa (Babaçual). As mulheres camponesas desenvolviam constantemente atividades econômicas em torno desse vegetal. Assim, as Quebradeiras de Cocos, como são conhecidas, processavam o fruto e dele retiravam uma variedade de produtos derivados, a saber, o leite, o azeite, o sabão, além do carvão feito da casca refugada após a retirada da castanha. Era desconhecida por parte dos moradores a utilização de vegetal que não fosse originário do coco Babaçu.

Imagem 2 - Floresta de Babaçu na Ilha de São José.

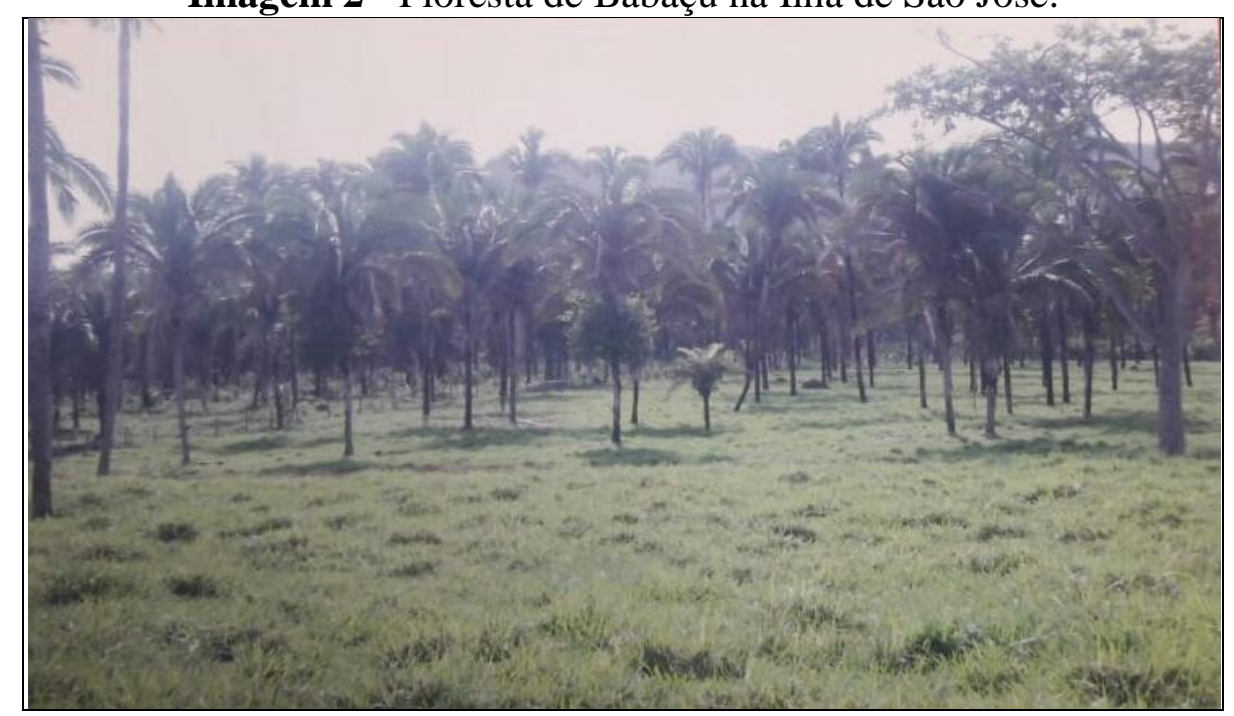

Fonte: organizado pelos autores.

A palha da palmeira era utilizada na cobertura das casas de Taipa, ou de Pau a Pique (Imagem 3) como é conhecida. O artesanato também se fazia presente, sobretudo pela utilização da fibra para a confecção de jacás, cestas, balaios, tipitis e outros. Assim, verificouse que o Babaçu influenciava diretamente no modo de vida dos camponeses da Ilha de São José, tanto econômica quanto culturalmente. 
Imagem 3 - Residência Camponesa na Ilha de São José.

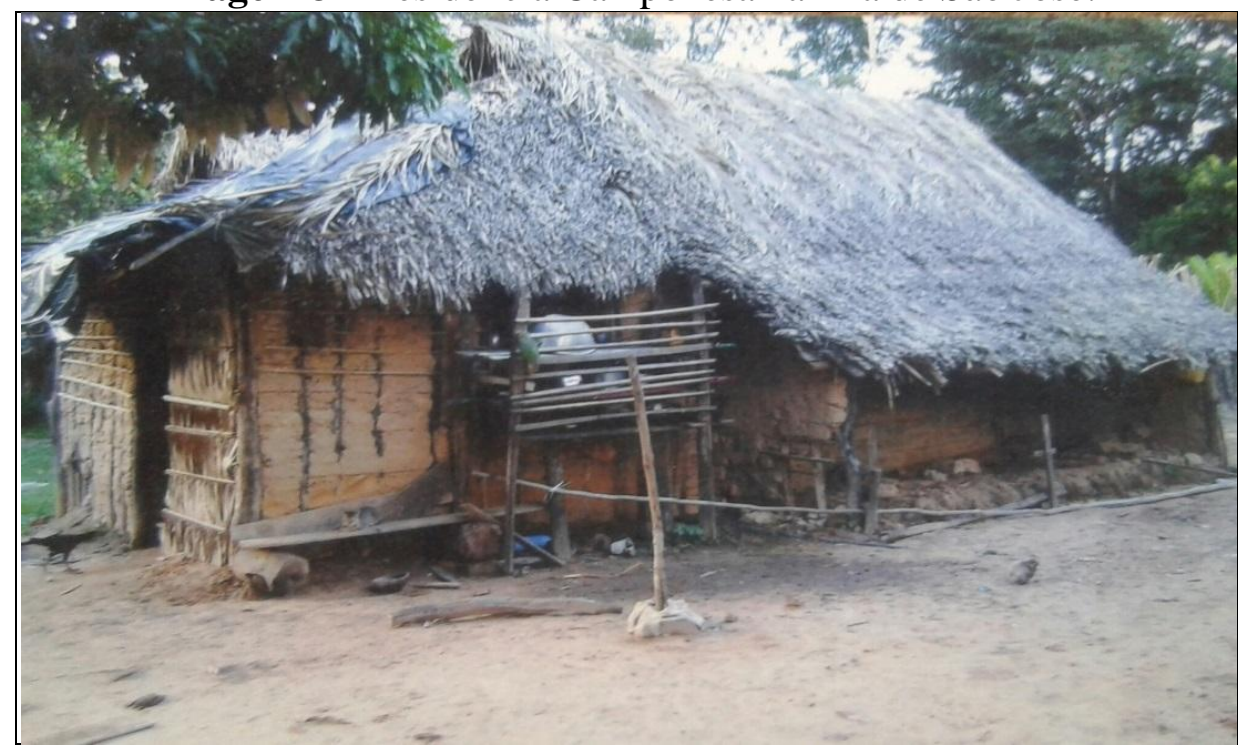

Fonte: organizado pelos autores.

Para além da agricultura, os camponeses da Ilha de São José eram autênticos pescadores. A fartura do rio Tocantins contribuía para a prática dessa atividade, fortalecendo, dessa forma, a qualidade da alimentação das famílias. Verifica-se, desse modo, o caráter polivalente da ação camponesa, não sendo ela limitada a um único ramo produtivo. Tal especificidade vai de encontro ao pensamento de Teodor Shanin, ao criticar a utilização de padrões fixos para a classificação do campesinato. De acordo com esse intelectual, “"um camponês', não existe em nenhum sentido imediato e estritamente específico", de modo que "Em qualquer continente, estado ou região, os assim designados diferem em conteúdo de maneira tão rica quanto o próprio mundo" (SHANIN, 2005, p. 1).

Ainda segundo Shanin (2005, p. 3), “as condições da vida produtiva camponesa necessitam e se moldam pelo estabelecimento de um ecossistema e um equilíbrio particular entre agricultura, atividade extrativa e artesanato, com uma ênfase particular no cultivo, mais do que na manufatura". Na Ilha de São José, como já foi exposto, a policultura era a marca registrada. Do meio ambiente era retirado o básico necessário à sobrevivência. Uma manufatura simples também era mantida pelas unidades produtivas, dela se originava produtos como o sabão, o azeite, o queijo, a tapioca e a farinha de mandioca, que asseguravam a independência dos camponeses frente ao mercado. O grosso da alimentação era integralmente produzido na ilha, plantava-se até mesmo café. A aquisição daquilo que não era produzido se dava após a comercialização do excedente. Com o equivalente geral (dinheiro)em mãos, o camponês podia ir novamente ao mercado, mas agora para concretizar o ciclo M-D-M, em que o primeiro M significa a produção excedente, o dinheiro embolsado 
com a sua venda, enquanto o segundo $\mathrm{M}$ corresponde às mercadorias adquiridas com D.O: querosene, o óleo diesel e os tecidos eram os principais exemplos de mercadorias obtidas no mercado pelas famílias. Esse fato, entretanto, não ligava o camponês de forma negativa ao mercado, uma vez que os produtos essenciais à sua reprodução já haviam sido produzidos na ilha.

Todavia, é importe ressaltar que o campesinato enquanto classe constituinte da formação social capitalista, não pode, de forma alguma, ser visto como "alienígena" ao modo de produção dominante (PAULINO, 2006). Esse grupo deve ser compreendido "através da investigação das características do estabelecimento rural familiar [...], tanto internas quanto externas, isto é, suas especificidades, reações e interações com o contexto social mais amplo" (SHANIN, 2005, p. 5). Desse modo, o escoamento da produção excedente se dava por meio de barcos, até as cidades de Estreito, Carolina e Babaçulândia, sendo as duas primeiras no Maranhão e a segunda no Tocantins. Esse intercâmbio ocorria com mais frequência aos finais de semana. O leque de mercadorias era formado por produtos de origem animal e vegetal, manufaturados e não manufaturados, tais comoo feijão, a laranja, a milho verde, a mandioca, a farinha, o azeite de coco Babaçu, a abóbora, as galinhas e os porcos. De acordo com Maria da Ilha, seis embarcações prestavam esse serviço, que era pago pelos próprios camponeses. A produção era vendida aos comerciantes nas margens do Tocantins, ou diretamente ao consumidor final nas feiras e mercados públicos. A cidade de Estreito era o principal destino das mercadorias; o avultoso mercado municipal situado na urbe contribuía para que as trocas fossem efetivadas. Os produtos que não encontravam clientes retornavam à ilha para serem estocados, consumidos ou utilizados como ração para os animais.

Portanto, fica claro que sem a geração do mais-produto (excedente), o camponês não seria capaz de adquirir o dinheiro necessário à aquisição das mercadorias que nãoproduzia. $\mathrm{O}$ excedente, por outro lado, "depende de vários fatores. De um lado, do número de braços na família. De outro lado, da fertilidade remanescente do terreno" (MARTINS, 2016, p. 160). Sendo assim, o conceito de economia de excedentes, formulado por José de Souza Martins, pode ajudar na interpretação do antigo quadro de vida dos camponeses da Ilha de São José. Nessa perspectiva, a família se torna a verdadeira responsável pelo cálculo da alíquota dos meios de vida que entrarão em circulação. Esse ato, como ficou claro, se dá após a separação do excedente daquilo que é necessário à subsistência; assim, "Mesmo que tais populações se tornem dependentes do mercado e dos pequenos comerciantes de seus povoados, seu vínculo 
mercantil será acessório, limitado e marginal, no sentido de que não é ele que organiza a totalidade do mundo camponês" (MARTINS, 2016, pp. 160-161).

O trabalho assalariado não constituía a base da produção; quando muito, havia a parceria, fenômeno que não diferenciava o campesinato. A propriedade dos meios de produção dava certa autonomia ao camponês insular. Todavia, essa dinâmica veio a se transformar drasticamente a partir do anúncio da implantação da Usina Hidrelétrica de Estreio. De acordo com Júlio da Silva (61 anos), camponês nascido e criado na Ilha de São José, os primeiros relatos e notícias acerca da construção da barragem se deram por volta do ano de 2000. Entretanto, os camponeses só vieram a confirmar as especulações sobre a usina em 2004, período em que foi realizado o Cadastro Socioeconômico das famílias que seriam atingidas pela hidrelétrica.

Um verdadeiro cenário de disputa foi criado a partir desses fatos; para Maria da Ilha, "O primeiro passo foi lutar contra a barragem". No ano de 2009, vários grupos de atingidos se mobilizaram para protestar contra as ações despóticas dos empreendedores. E durante mais de 1 ano permaneceram acampados próximo ao canteiro de obras da barragem, localizado na rodovia BR 010 (Estreito MA). Nesse período, Maria da Ilha se encontrava na linha de frente do acampamento; todos os mobilizados eram mantidos pela parte da população que permanecera na lavra da terra. Não havia distinção de segmentos econômicos, todos os sujeitos ali presentes representavam uma única classe, a dos atingidos pela barragem de Estreito. $\mathrm{O}$ acampamento contou com o apoio irrestrito do MAB, durante toda a sua vigência.

Na Ilha de São José, como em todo caso, o processo de expulsão foi doloroso. Após a confecção do Cadastro Socioeconômico muitos camponeses deixaram de produzir o excedente, apoiados no argumento de que as suas atividades produtivas estavam fadadas à destruição. Os últimos 4 anos na ilha foram marcados pela estagnação das forças produtivas, resistindo apenas a produção no nível de subsistência. Declinou-se, por conseguinte, as inversões de dinheiro nas propriedades, fator que era determinante no alargamento da produção.

A condição mental dos sujeitos também foi abalada pelo despotismo das ações implementadas pelo CESTE. Dentre os inúmeros descasos ocorridos, a perícia econômica realizada nas propriedades se configura como uma das mais eminentes. Ratificada sem o consentimento dos atingidos, essa ação causou grande revolta entre os camponeses da ilha, sobretudo pela sua falta de lisura. Os inventários ficaram ao cargo de uma empresa contratada 
pelo próprio consórcio; assim, todas as propriedades foram avaliadas abaixo de seus valores reais, beneficiando, desse modo, os empreendedores.

A atuação do CESTE acabou por fragmentar os camponeses, de modo que a última resistência passou a ser o grupo liderado por Maria da Ilha, formado por 35 famílias. Os empreendedores tentaram de todas as formas inviabilizar essa organização. Propostas irrisórias foram feitas aos camponeses da Ilha de São José, a carta de crédito era uma delas. Essa modalidade indenizatória consistia no repasse de dinheiro ao atingido, cabendo ao próprio camponês buscar por uma propriedade rural ou urbana, a ser comprada, e que respeitasse o limite orçamentário da empresa; Maria relata que "A carta de crédito mais valiosa que apareceu foi no valor de 45 mil reais", valor abaixo da realidade. A ilusão monetária, verificada em muitos casos por Sieben (2012), não se fez presente no grupo comandado por Maria da Ilha. Todos sabiam o real valor de suas terras. A carta de crédito livrava os empreendedores de terem que organizar uma nova moradia coletiva para os atingidos. O grupo resistiu até o momento em que houve a possibilidade de se adquirir "terras mais produtivas". A essa altura, a resistência contava apenas com 18 famílias, consequência das fortes pressões promovidas pelos representantes do CESTE.

As investidas foram incessantes, mas as 18 unidades produtivas mantiveram-se unidade até o final. O discurso ameaçador era sempre utilizado contra os ribeirinhos; muitos camponeses receberam forte pressão para deixar a resistência. A mãe de Gerdean Carvalho, dona Dorivan Carvalho (62 anos), camponesa matriarca da ilha, foi procurada por membros do consócio para que recebesse um valor maior do que o usual pela sua propriedade, mas em contrapartida deveria abrir mão do assentamento restituitório. Dessa forma, o consórcio visava à fragmentação do grupo, para que as despesas indenizatórias se tornassem menos elevadas. Entretanto, todas essas investidas foram em vão, e o grupo não se fragmentou daí em diante.

A fazenda Mirindiba, localizada em Araguaína, foi a escolhida pelos camponeses, e não houve objeção por parte dos empreendedores. No mesmo ano da compra, 2010, teve início a formação dos lotes, construção das moradias e delimitação da reserva. Todo esse processo foi acompanhado de perto pelos atingidos. Essa conquista demonstra a capacidade de organização do campesinato; caso o consórcio tivesse obtido êxito no desmonte do grupo, essas famílias teriam sido remanejadas para os assentamentos já existentes, onde as condições de vida são precárias, sobretudo pela hostilidade do ambiente físico. Conclui-se, portanto, que: 
"A reivindicação principal do campesinato é a posse e o uso da terra. Luta para preservar, conquistar ou reconquistar o seu objeto e meio básico do trabalho e vida. Em face da acumulação originária, ou do desenvolvimento extensivo e intensivo do capitalismo no campo, o camponês luta pela terra. Reage à sua expulsão do lugar em que constrói a sua vida. E essa luta frequentemente adquire conotação revolucionária." (IANNI, 2009, p. 142).

Todavia, mesmo após essa última negociação o conflito ainda continuou. O impasse agora girava em torno das indenizações relativas às benfeitorias existentes nas propriedades da ilha. Esse direito não foi assegurado pelo CESTE, vindo a causar grande turbulência entres os camponeses. Não sendo atendidos pelos empreendedores, os ribeirinhos resolveram buscar a justiça. Em virtude disso, o grupo de 18 famílias, em forma de protesto, não deixou a Ilha de São José até que se esgotassem todos os prazos "legais" estipulados pelo consórcio; sendo alvo constante de intimidações por parte dos representantes do CESTE. Em meio a esses fatos, um incêndio criminoso consome grande parte da ilha. As famílias que ainda restavam entraram em desespero ao verem a vegetação sendo consumida pelo fogo. Um boletim de ocorrência foi confeccionado, mas os responsáveis nunca foram encontrados. Entretanto, na cabeça dos camponeses não havia dúvida de quem eram os criminosos. Maria da Ilha procurou o Ministério Público na cidade de Araguaína, onde foi orientada juridicamente acerca dessa questão, todavia, até hoje ninguém foi penalizado.

Amparado pela instância jurídica, o CESTE conseguiu a ordem de despejo dos camponeses da Ilha de São José, no ano de 2010. A decisão judicial foi executada por forças policiais. Dona Dorivan, por exemplo, foi retirada de sua propriedade por cerca de 50 policiais bem armados; bastante abatida, não fazia outra coisa senão chorar. Não há dúvida de que a polícia é a garantidora das vontades dos poderosos; a energia daqueles que governam, e a expressão imediata do aparelho repressivo do Estado, que segundo Althusser (1970, p. 46), funciona pela violência.

Gerdean Carvalho relata também as dores de sua conturbada partida. O consórcio, como de costume, fez falsas promessas aos camponeses. Havia um acordo firmado entre as partes, de que embarcações seriam fornecidas para levar aquilo que os ribeirinhos julgassem necessário. Todavia, esse compromisso não foi respeitado pelo CESTE, que deu continuidade ao despejo; "Foi uma tristeza ver o trator derrubando minhas plantações, meus pés de laranja...”, diz Gerdean. Quando verificou que não havia a possibilidade de levar o mínimo necessário para o recomeço, Gerdean cai no desespero. Num ato corajoso e impulsivo, o camponês se lança na frente da máquina em sinal de protesto: num tom destemido, ele afirma 
que nada mais seria derrubado na propriedade, até que viessem embarcações suficientes. $\mathrm{O}$ operador, visando à intimidação do camponês, conduziu o veículo a até poucos centímetros do homem desarmado. Gerdean manteve a sua postura, e sem qualquer arrependimento afirma que: "Naquele dia eu estava pronto para morrer, falo isso aqui ou em qualquer outro lugar, eu estava pronto para morrer".

Os executores vendo que a situação não se resolveria, deixaram a propriedade e, no dia seguinte, retornaram com embarcações suficientes. Esse fato representa não só a vitória de um homem perante uma ação dos poderosos, mas também a sua coragem. Desse processo de expulsão resultou a formação do assentamento Mirindiba; a migração forçada trouxe consigo a possibilidade de continuidade do modo de vida em um outro lugar. A formação e a dinâmica desse assentamento serão tratadas na sequência, além dos desafios impostos a esses camponeses.

\section{Assentamento Mirindiba, o novo território}

O território, como se sabe, é marcado por diferenciações em sua configuração; daí a singularidade de cada lugar. Olivier Dollfus (1991) afirma que, pela "localização e pelo jogo de combinações que preside a sua evolução, todo elemento do espaço e toda forma de paisagem constituem fenômenos únicos que jamais podem ser encontrados exatamente iguais em outros locais ou em outros momentos" (DOLLFUS, 1991, p. 9). O assentamento Mirindiba é um exemplo claro dessa diferenciação, já que esse novo território possui características distintas do território original, a Ilha de São José. A dinâmica social do campesinato não deve levar em conta os aspectos da velha morada, mas sim os do lugar atual, que é palco e ator das relações de produção efetivadas pelas famílias.

O território é o firmamento da existência humana. Os sistemas de ações criados pelas necessidades materiais da sociedade estão intimamente ligados ao meio. Para Max Sorre (2003), "trata-se de uma relação recíproca, posto que por meio da técnica os homens modificam o ambiente natural, ao tempo que se adaptam a ele" (SORRE, 2003, pp. 138-139). Para tanto, a natureza deve ser vista como um sistema fundamental à existência da sociedade, sendo ela o "seu armazém original de meios de subsistência" e o "seu arsenal originário de meios de trabalho" (MARX, 2013, p. 257).O território se torna o alicerce de sua própria mudança, já que oferece à sociedade todas as condições objetivas de transformação. Essa 
dinâmica, de um modo geral, está atrelada ao fato de "A natureza não está, nem objetiva nem subjetivamente, imediatamente disponível ao ser humano de modo adequado" (MARX, 2008, p. 128). Portanto, a “construção do espaço geográfico", nada mais é do que“[...] o processo histórico do distanciamento do homem em relação ao mundo natural" (CAMPOS, 2001, p. 93).

Mesmo tendo novas condições de reprodução, os camponeses não tiram a ilha da cabeça. Ela representava o espaço geográfico construído ao longo de várias gerações, o território usado de forma tradicional, símbolo incondicional daquela população. As lembranças são marcas que não podem ser apagas facilmente, sobretudo pelo fato de "Os espaços construídos” possuírem "dimensões materiais, concebidas e vividas” (HARVEY, 2015, p. 138).

Mesmo com grandes percalços, os camponeses formadores do assentamento Mirindiba não hesitaram em lutar pela continuidade do seu modo de vida. As contradições do próprio modo de produção capitalista asseguram a (re)existência do campesinato, já que "ao mesmo tempo em que expropria, abre a possibilidade histórica do retorno a terra, em geral em lugares distantes daqueles primeiros" (OLIVEIRA, 2001a, p. 50). Muito dos camponeses da Ilha de São José foram realocados no próprio município de Babaçulândia, outros em Araguaína, e os demais em localidades próximas; o Quadro 1 traça um panorama dessa realidade.

Quadro 1 - Novos Locais de Moradia dos Camponeses Expulsos da Ilha de São José.

\begin{tabular}{|c|c|c|}
\hline Assentamento & Município & Quantidade de Famílias \\
\hline Mirindiba & Araguaína & 18 \\
\hline Bela Vista & Babaçulândia & 12 \\
\hline Baixão & Babaçulândia & 26 \\
\hline Santo Estevão & Babaçulândia & 1 \\
\hline Palmeiras & Palmeiras do Tocantins & 12 \\
\hline \multicolumn{2}{|c|}{ Total de Famílias } & 69 \\
\hline
\end{tabular}

* As 5 famílias restantes optaram pela Carta de Crédito cedida pelo CESTE, segundo informações dos demais camponeses. Fonte: organizado pelos autores.

Para todos os efeitos, o assentamento Mirindiba (Mapa 2) está localizado na zona rural de Araguaína; a entrada que dá acesso ao local está situada na BR-153, na altura do km 164.Distante $7 \mathrm{~km}$ da rodovia, o assentamento também está situado a cerca de $30 \mathrm{~km}$ do centro da cidade de Araguaína, o coração econômico da região.

A fazenda Mirindiba, da qual foi originado o assentamento homônimo, era de propriedade de Cassimiro José Taveira, o segundo vice-prefeito da história política de Araguaína (1966-1969). Representava o casamento da elite rural e política, fenômeno típico 
da região. Por meio da hereditariedade da propriedade privada, esse latifúndio chegou até os dias de sua venda ao CESTE, como sendo patrimônio da mesma família. Assim, uma única propriedade abriga hoje 21 unidades produtivas. Isto evidencia claramente o processo de concentração fundiária do país. Ariovaldo Umbelino de Oliveira dá uma explicação plausível acerca da lógica por trás das grandes propriedades no Brasil; segundo o autor, "A retenção da terra não é feita com fins de colocá-la para produzir", esse é, na verdade, o "motivo pelo qual a maioria das terras deste país mantém-se improdutiva [...]. retida com a finalidade de constituir instrumento a partir do qual se vai ter acesso por parte, evidentemente, das elites às políticas do Estado" (OLIVEIRA, 2001b, p. 199). Os financiamentos por meio de bancos públicos são os exemplos mais claros dessa lógica.

Mapa 2 - Localização do Assentamento Mirindiba.

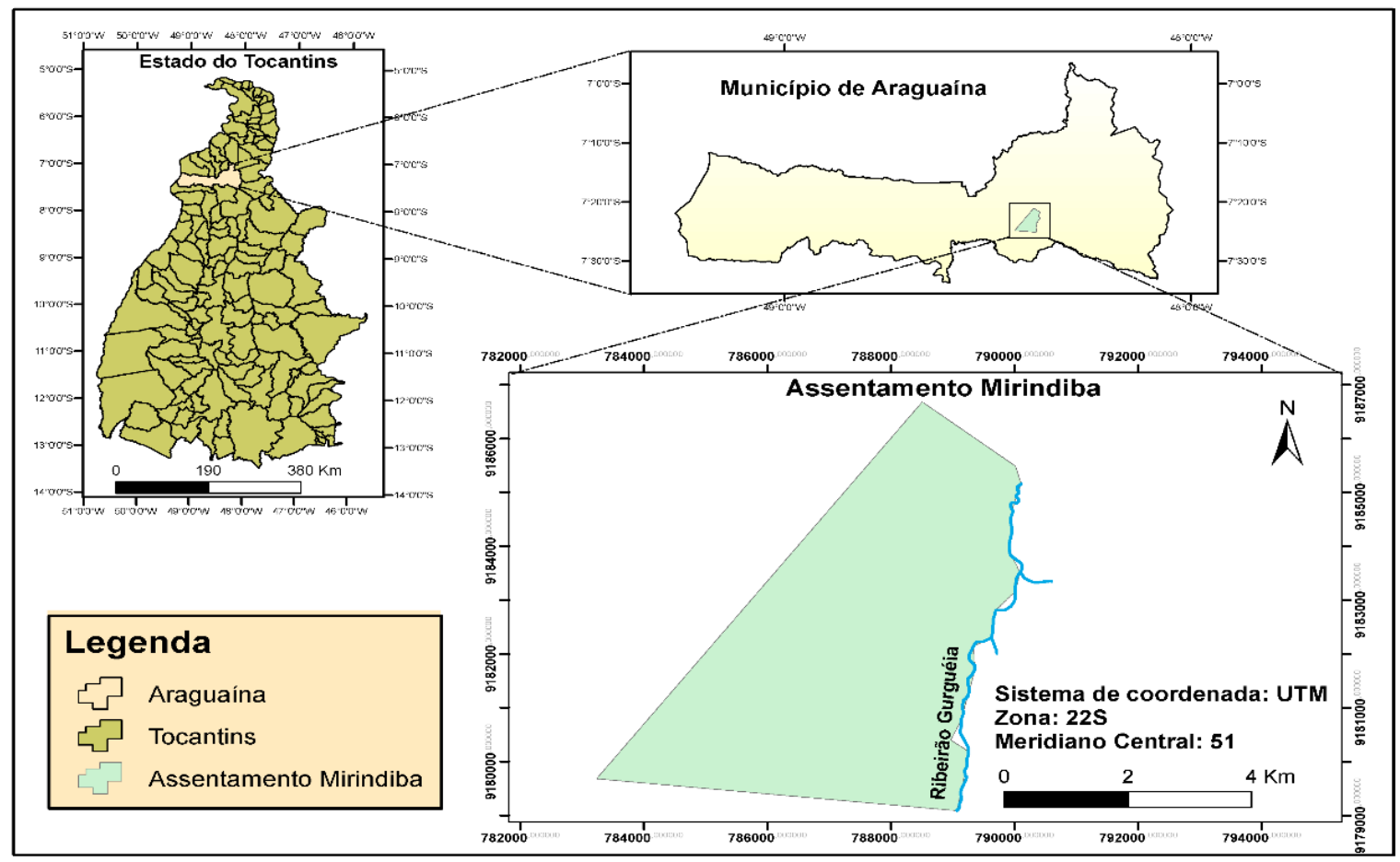

Fonte: SEPLAN-TO. Organizado pelos autores.

O assentamento é o reflexo imediato da luta camponesa no interior da sociedade capitalista. O grupo de 18 famílias lutou até as últimas instâncias pelas suas terras; muito embora não comparáveis às propriedades da ilha, são, indubitavelmente, melhores do que as dos demais assentamentos criados pelo CESTE. Por isso, Maria da Ilha afirma que no assentamento Mirindiba "foi pago R\$ 25 mil no alqueire de terra", enquanto "Nos assentamentos de Babaçulândia foi pago R \$ 5 mil no alqueire de terra... As terras lá são ruins, nem a água nunca prestou”. A chegada ao novo território ocorrera no dia 4 de agosto de 2010, 
4 meses antes do início do enchimento do reservatório. O grupo de 18 famílias sofrera um acréscimo de mais3 unidades produtivas, oriundas de novos casamentos. Esses integrantes, entretanto, não receberam lotes, já que surgiram após o processo de formação do assentamento, os mesmos ocupam áreas cedidas no interior das parcelas já existentes, sendo qualificados como agregados.

O cadastro socioeconômico, realizado pelo CESTE, dividiu os camponeses da Ilha de São José em dois segmentos: agricultores e pecuaristas. Tal subdivisão serviu como base para o cálculo da área das novas propriedades. Em virtude disso, as parcelas foram organizadas da seguinte forma: às famílias agricultoras e pecuaristas foram concedidos $6,8 \mathrm{e}$ 21,7 hectares de terra a cada unidade respectivamente. Todavia, como forma de cumprimento à legislação vigente, cada propriedade teve que fornecer uma parte de sua área à reserva florestal comum. Assim, cada lote contribuiu com 30\% de sua área original, logo, as propriedades tiveram os seguintes números em suas dimensões finais: 4,76 hectares aos agricultores e 15,2 hectares aos pecuaristas. Ao todo foram distribuídos 15 lotes para pecuaristas e 3 para agricultores. Entretanto, cabe salientar que tal subdivisão nada mais é do que uma estratégia do consórcio para diminuir os gastos indenizatórios. Os camponeses da Ilha de São José não eram agrupados por ramos de atividade; eram polivalentes, atuando em várias frentes, de modo que tal classificação não condiz com a realidade vivenciada no antigo território.

\section{A luta pela continuidade do modo de vida camponês}

No assentamento Mirindiba, o choque foi imediato; os camponeses se viram diante de uma realidade catastrófica. Nada era como antes, daí a sensação de insegurança, pois o novo território precisa ser compreendido. Um camponês relata a sua chegada ao assentamento: "Quando eu cheguei aqui [em Mirindiba], no outro dia acordei e pensei que eu estava tipo no espaço; parei... E disse: 'Meu Deus!' Onde é que eu estou?’. Esse sujeito viveu toda a sua vida na Ilha de São José, e agora na velhice sofre o drama da impotência frente aos atores hegemônicos, que desculturalizam inúmeras comunidades tradicionais em prol de seus interesses econômicos. Outro camponês afirma que:

"O choque já aconteceu na mudança; quando eu cheguei aqui é de imaginar, o cara olha para os lados, e pensa que você vivia num sítio, você chupava uma lima, você chupava uma laranja, você comia uma goiaba, você pega 
uma cajá lá no pé, está entendendo? Você bebia uma água de um coco a hora que você queria; você está entendendo? E depois chegar aqui "bicho", e sentar nessa calçada, eu vou te falar: eu só não chorei por que..., mas eu sentei nessa calçada e fiquei imaginando minha vida; só o "capimzinho" velho feio aqui ao redor e a casa" (Gerdean Carvalho, 40 anos).

O que o camponês descreve é o processo de estranhamento promovido pela infraestrutura econômica. De fato, "O mundo capitalista no qual vivemos, sugere que o capital é mais importante que os indivíduos. As hidrelétricas são mais uma maneira que se tem de acumulação de capital" (SANTOS; SIEBEN, 2014, p. 7). Inicialmente, as condições de vida eram precárias, mesmo sendo o assentamento Mirindiba o de maior potencial dentre os demais. A primeira dificuldade observada foi a péssima estrutura das moradias, que necessitavam urgentemente de adequações (Imagem 4). Todas as modificações realizadas pelas famílias foram custeadas por elas próprias.

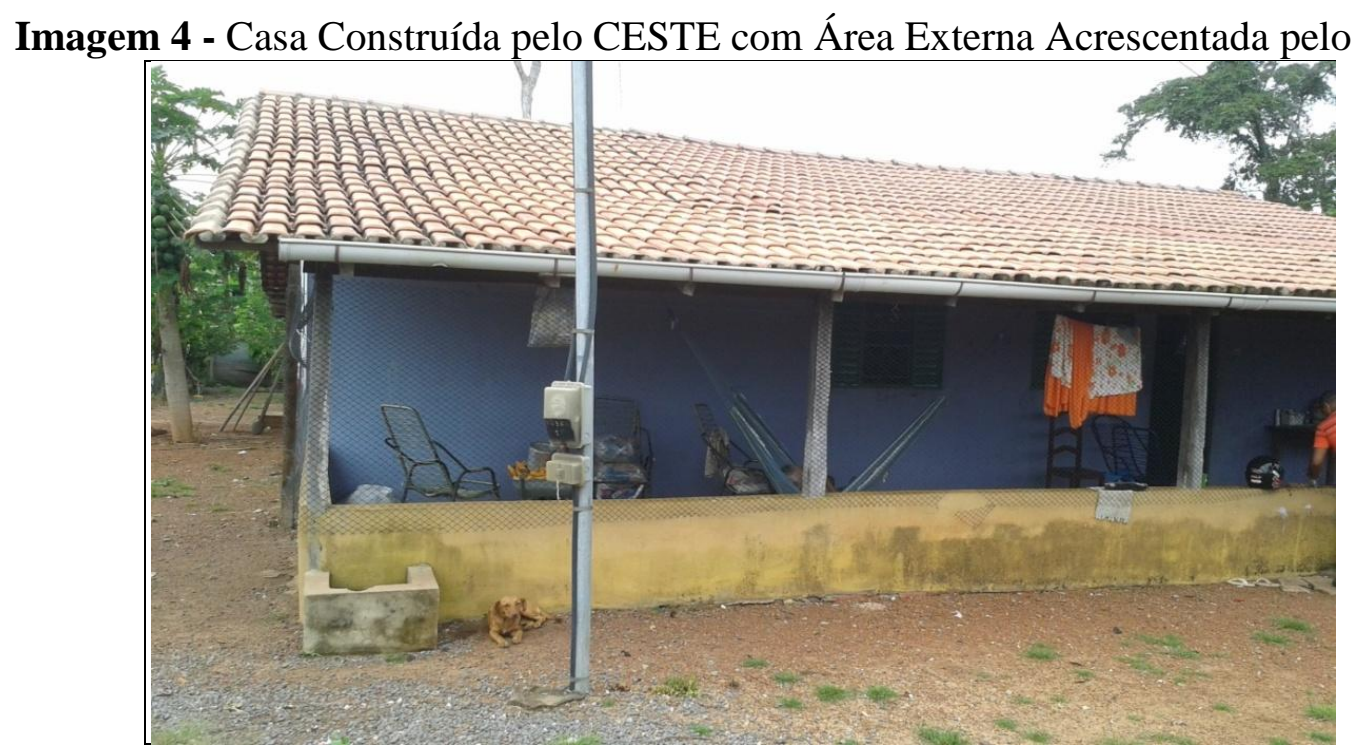

Fonte: Organizado pelos autores.

Por esse e mais motivos o CESTE foi o responsável pela ineficiência produtiva dos camponeses após a chegada ao assentamento. A fazenda Mirindiba, como muitas outras da região, é o reflexo da estrutura fundiária do país. Nesse caso em especial, a atividade desenvolvida era a pecuária extensiva; os bovinos eram criados na vasta extensão de terras do latifúndio, tendo como base as pastagens artificiais. Depois de adquirida pelo consórcio, a fazenda passou por um processo de aragem do solo, fato este que provocou o soterramento do capim formador da vegetação. Segundo os camponeses, esse foi um fator decisivo para o baixo nível de produtividade do trabalho. Maria da Ilha relata que: "Quando eles araram a terra, logo depois nós já plantamos o arroz, mas deu uma febre, não nasceu um pé de arroz... 
Esquentou o arroz, esquentou o feijão e não nasceu nada! Isso nos dois primeiros anos". O capim soterrado fez com que a temperatura do solo aumentasse, e, desse modo, comprometesse a produção das unidades produtivas. Essa condição fez com que os camponeses recorressem aos empreendedores que, durante 2 anos, subsidiaram os camponeses por meio da entrega de mantimentos e ajuda em dinheiro, ambos insuficientes.

A baixa produtividade do solo tem feito com que os camponeses recorram ao mercado de forma mais significativa. Um produto como o arroz, produzido de forma excedente na ilha, se torna inexistentes nas lavouras do Mirindiba. Por isso, uma camponesa se assusta ao relatar que: "Hoje mesmo eu fui ao mercado; eu não tinha costume de ir... Ia apenas para comprar alguma 'coisinha'... Aí a gente vai ao mercado comprar o arroz; o que mais me assusta é o fato de termos que comprar arroz". De acessória, a ida ao mercado passa a se tornar cada vez mais uma dependência.

O novo território representava o desconhecido, um mistério a ser desvendado. Uma camponesa narra o seu temor em relação à nova morada: "Quando eu vim da ilha para cá, eu trouxe uns 50 litros de água! Era um trauma". A experiência dos demais assentamentos fez com que o medo tomasse conta do grupo liderado por Maria da Ilha. Os demais assentamentos estão em piores condições, todos sofrem com a ausência de cursos d'água perenes. O rio Tocantins não faz mais parte do cotidiano dos assentados, em seu lugar hoje existe apenas o ribeirão Gurgueia que corta a antiga fazenda Mirindiba, mas sendo tecnicamente inviável o seu uso pelas famílias. A falta de água eminente fez com que o CESTE providenciasse, desde o início, a perfuração poços artesianos, além da instalação de bombas, filtros e construção de reservatórios (Imagens 5-6).

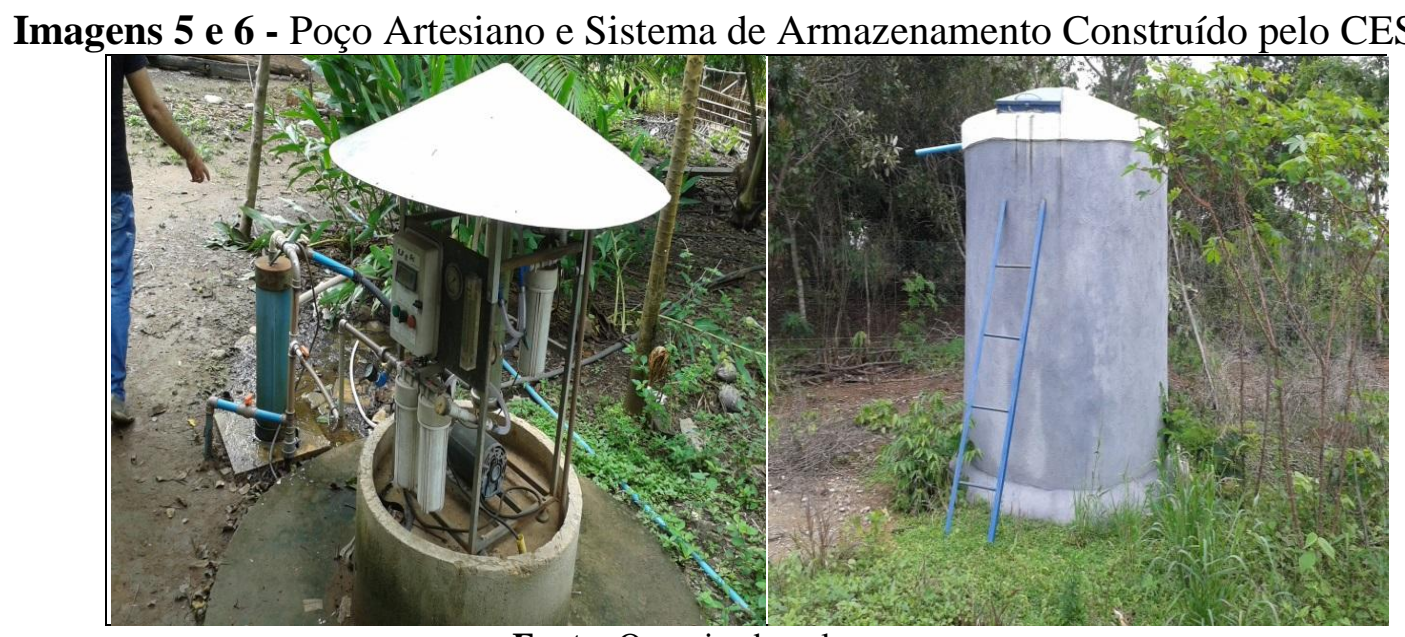

Fonte: Organizado pelos autores. 
Mesmo nessas condições, o camponês migrante não se deixa abater pelas dificuldades. Apesar da insuficiência dos sistemas técnicos implantados pelo CESTE, esse sujeito social não perde a esperança em dias melhores. A arma principal dessa classe é a perseverança, já que o campesinato brasileiro é, acima de tudo,

\begin{abstract}
"Um migrante e sua expropriação não tem representado uma ruptura total de seus vínculos com a terra. A maioria deles mantém alguma relação com o campo, seja ela mais próxima ou mais distante - relação direta de trabalho, vínculos familiares, relação de origem etc.” (MARQUES, 2008b, p. 65).
\end{abstract}

Os camponeses foram à luta e conseguiram um suporte técnico por parte do CESTE; os empreendedores prestaram assistência aos assentados por meio do Instituto de Desenvolvimento Rural do Tocantins (RURALTINS). Esse apoio consistia no acompanhamento agronômico, e visava intensificar as práticas agroecológicas no seio das unidades produtivas. O MAB esteve presente como agente fiscalizador, entretanto, como ressalta Fabrini (2008, p. 247), "existe uma prática de resistência entre os camponeses que extrapola os limites dos movimentos sociais", há na verdade, "uma resistência para além dos movimentos sociais, como se existisse um 'movimento camponês' mais amplo do que os "movimentos sociais"'. Essa obstinação natural do campesinato foi a responsável pela resistência das famílias do assentamento Mirindiba.

O campesinato manteve-se firme e sempre disposto a batalhar contra aqueles que desejavam a sua destruição. Por isso, parte-se aqui das premissas de Ariovaldo Umbelino de Oliveira, quando o mesmo reconhece duas vertentes do campesinato no Brasil: a primeira diz respeito aos que lutam para entrar na terra, ou seja, aqueles que ainda não possuem qualquer vínculo com a posse ou propriedade da terra; a segunda contempla os que lutam para permanecer na terra, ou seja, aqueles que já a possuem, mas que são constantemente testados pelas dificuldades produtivas, pela falta de apoio do Estado e também pela violência dos latifundiários (OLIVEIRA, 2001b). Logo, os camponeses do assentamento Mirindiba fazem parte do grupo dos que "lutam para permanecer na terra como produtores de alimentos fundamentais à sociedade brasileira" (OLIVEIRA, 2001b, p. 189). Esses sujeitos reclamam o direito pela continuidade do seu modo de vida; a posse da terra já é algo concreto, apesar de as questões jurídicas referentes aos títulos definitivos ainda assustarem os camponeses. De certo, pode-se afirmar que no caso em questão não há luta para entrar na terra, mas sim para permanecer. Deriva daí a batalha principal das famílias do assentamento Mirindiba.

Portanto, o termo camponês é sinônimo de resistência, sobretudo de: 
"Resistência ao modo de produção atual que os nega na mesma intensidade que os mantêm e apropria-se do seu labor. Resistência aos donos da terra, aos que detêm o domínio sobre ela e que os subjugam enquanto classe inferior. Resistência ao Estado, fiel defensor dessa estrutura social hierarquizada e que está a serviço daqueles que ocupam o topo da pirâmide. Resistência a terra, ou a ausência dela, que por sua vez, faz emergir a esperança." (MARINHO; LIRA, 2018, p. 199).

A propriedade da terra em si não tem significado para o camponês, esta deve vir acompanhada de trabalho; essa classe não sobrevive à custa de rendas ou da exploração da força de trabalho alheia. Por não se enquadrar nas relações típicas do capitalismo, a unidade produtiva camponesa deve ser vista como uma contradição dentro do sistema burguês (OLIVEIRA, 1981; 1987; 2001a; 2001b; 2005; 2007) e entender sua existência, de acordo com Oliveira (2001a, p. 11), significa, na verdade, "entender o desenvolvimento desigual do modo capitalista de produção na formação social capitalista, significa entender que ele supõe sua reprodução ampliada, ou seja, que ela só será possível se articulada com relações sociais não-capitalistas".

No assentamento Mirindiba, a produtividade do trabalho sofreu alterações expressivas, mas que não significou a ruína das famílias. O modo de agir do campesinato se adequa às condições adversas. O campesinato que chegou ao novo território em 2010 não é exatamente o mesmo da atualidade. Pondo um pouco as dificuldades de lado, as famílias vêm mantendo um nível de vida que afasta qualquer tendência à proletarialização. Quando interrogado sobre a sua produção, um camponês responde:

\footnotetext{
"Rapaz! Eu no segundo ano quando eu comecei a trabalhar aqui... Eu plantei muita mandioca. A terra foi preparada, colocaram calcário e foi jogado adubo, aí deu muita mandioca; isso foi em 2012. Em 2013 eu já fiz outra roça que deu umas 1.200 caixas de mandioca, foi muito bom! Daí para cá eu não plantei muita mandioca, porque foi ficando fraca [a terra]. Também fiz um bananal, eu vendi muita banana." (Gerdean Carvalho, 40 anos).
}

A lavoura de mandioca (Imagem 7) é de longe a mais significativa: é comum entre os camponeses comentários do tipo: "mandioca nasce em qualquer chão" ou "a mandioca basta plantar”. De fato, a adaptabilidade da raiz é imensa; a sua produção não exige tantos gastos com adubo, diferentemente do milho, por exemplo. A economia em torno do vegetal não se resume apenas à sua venda in natura, se estendendo também a uma gama de produtos derivados de sua manufatura.

A mandioca representa a principal lavoura, mas não a única. Esse artigo é a base da produção porque o mercado o acolhe, e não pela livre escolha dos camponeses. Nas propriedades é plantado de tudo, mesmo que em proporções diferentes; o milho, o feijão, o 
maracujá, a abóbora, a melancia, a pimenta, a cebola e o coentro são observados com frequência. Entre os animais criados nas propriedades destacam-se os bovinos, as galinhas e os porcos. A policultura não é abandonada, por mais que o mercado pressione as famílias. Um camponês relatou que a prática da pecuária bovina lhe poupa os gastos com adubo, já que os dejetos do rebanho são utilizados como fertilizante natural.

\section{Imagem 7 - Plantação de Mandioca.}

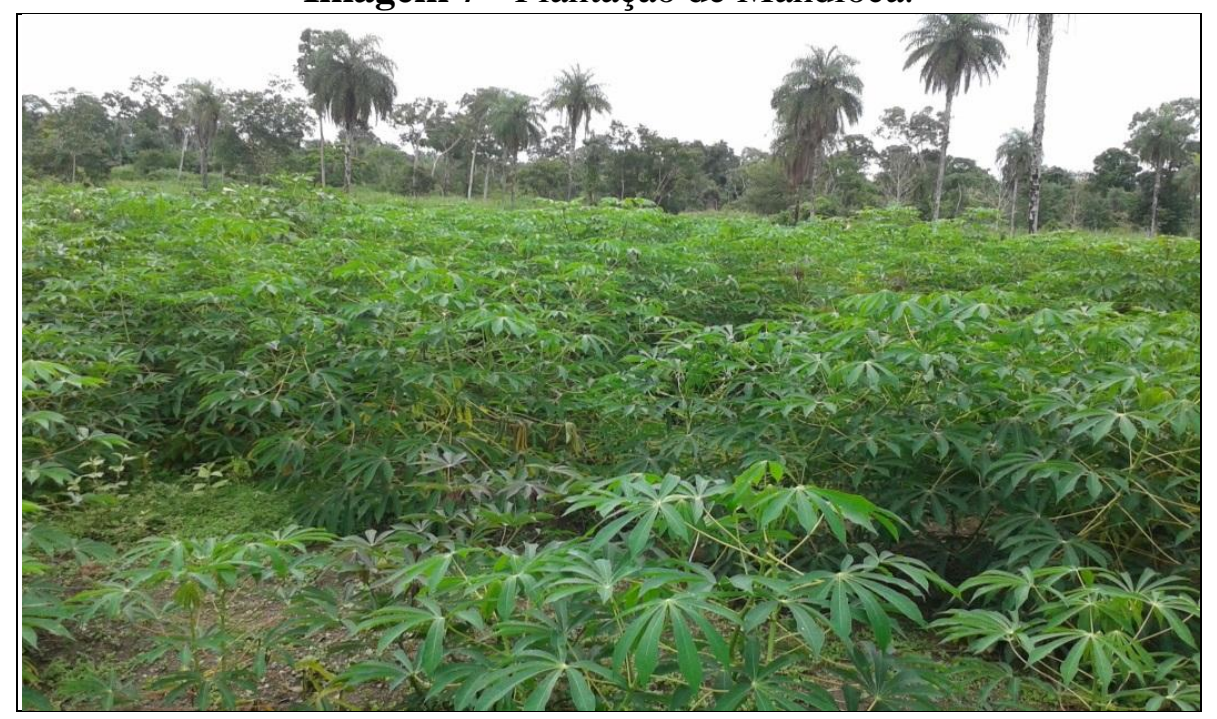

Fonte: Organizado pelos autores.

O campesinato do assentamento Mirindiba produz valores de uso, isso deve ficar claro. Os artigos comercializados foram produzidos inicialmente para satisfazer alguma necessidade da unidade produtiva. O milho (Imagens 8-9), por exemplo, serve de alimentação para as galinhas, porcos e cavalos; e se colhido verde pode ser consumido pelas famílias. A mandioca cozida é consumida como alimento suplementar pelos camponeses, da mesma forma que os seus derivados (farinha, puba, mingau); a raiz também pode ser dada como ração aos porcos. Assim, "na economia camponesa, prevalece a produção valores de uso para o autoconsumo, diferentemente do modo de produção capitalista, que produz valores de troca" (CARNEIRO, 2009, p. 55).

A primeira necessidade do camponês não é a de comparecer ao mercado como possuidor de mercadoria, mas sim a de produzir aquilo que lhe forneça alguma utilidade. Um grande produtor de soja não produz dessa forma, ele o faz pensando no retorno monetário que a sua mercadoria pode trazer; "Para ele, o único valor de uso que ela [mercadoria] possui diretamente é o de ser suporte de valor de troca e, portanto, meio de troca. Por essa razão, ele quer aliená-la por uma mercadoria [dinheiro] cujo valor de uso o satisfaça" (MARX, 2013, p. 160). 
Imagens 8 e 9 - Plantações de Milho em Diferentes Estágios no Assentamento Mirindiba.

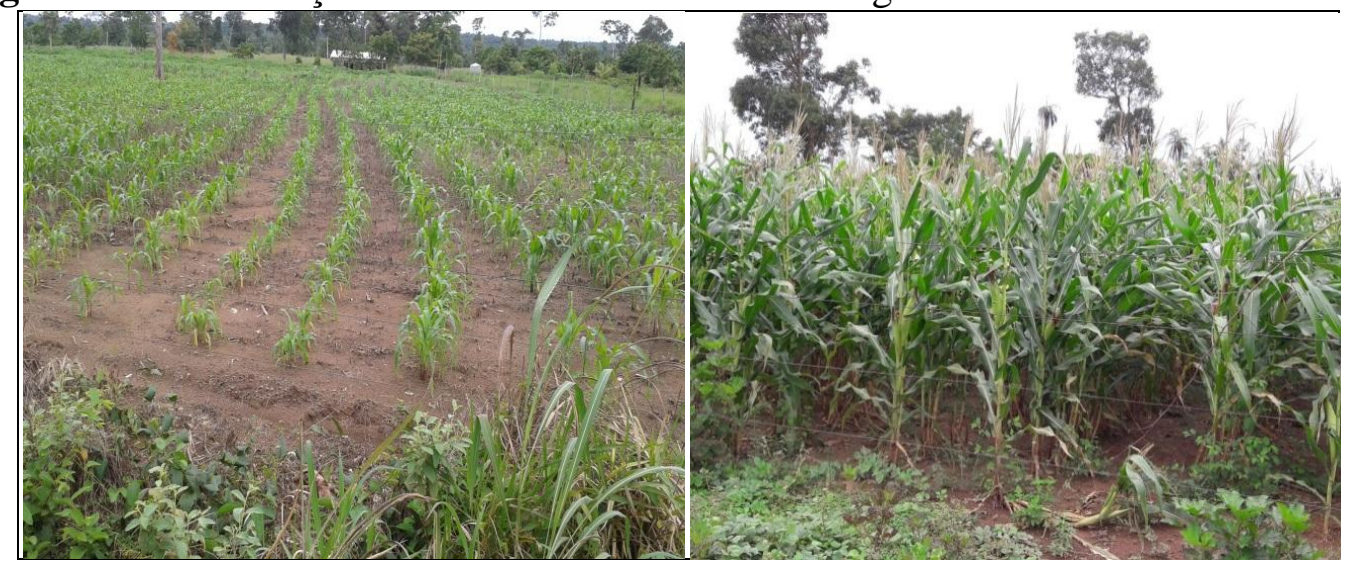

Fonte: Organizado pelos autores.

O campesinato também transforma produtos em mercadorias, mas só depois de tê-los produzido de forma excedente. Na agricultura camponesa, a produção está pautada na reprodução da vida imediata dos membros da família. De fato, se o camponês pudesse produzir tudo o que necessita sem precisar recorrer ao mercado, ele o faria. No assentamento Mirindiba também vigora a agricultura de excedentes, não como na Ilha de São José obviamente, mas pelo fato de o mercado ser confrontado somente após a separação do produto excedente. Nessa agricultura,

“O excedente já aparece como tal na própria produção. O essencial nessa interpretação é que os meios de vida do agricultor não são imediatamente estabelecidos pela mediação do mercado. Mesmo que o camponês venha a ter que comercializar também parte de seus meios de vida, ele sabe que está vendendo aquilo que originalmente fora destinado à sua sobrevivência." (MARTINS, 2016, p. 159).

Dessa liberdade não goza o trabalhador assalariado, que não sabe distinguir a parte da jornada de trabalho que virá a se transformar nos seus meios de vida, do trabalho excedente a ser apropriado pelo capital (MARTINS, 2016). Não é estranho ao campesinato o fato de a força de trabalho ter "a propriedade especial de ser uma força criadora de valor, uma fonte de valor e, principalmente com um tratamento adequado, uma fonte de mais valor do que ela própria possui” (ENGELS, 2010, p. 28). O trabalho dos membros da família camponesa é capaz de produzir bem mais produtos do que necessitam; a inserção dessa classe no mercado se dá principalmente por esse motivo. Quando a mandioca é comercializada, por exemplo, significa dizer que a produção superou as necessidades da família.Com a venda desse maisproduto,o camponês adquire o equivalente geral (dinheiro), que o habilita a ir novamente ao mercado,e comprar aquilo que a unidade familiar não produz diretamente no assentamento. 
A economia de excedentes assume uma nova roupagem, sobretudo em relação aos produtos da base alimentar. De fato, a produção camponesa não perdera o seu viés natural, que é a produção de valores de uso, todavia, não se pode negar que a relação desses sujeitos com o mercado mudou consideravelmente. $\mathrm{Na}$ ilha, apenas os produtos acessórios eram adquiridos. Agora, a realidade se inverteu parcialmente, artigos como o arroz, o feijão e a carne precisam ser comprados periodicamente nos supermercados de Araguaína. O novo território deu margem para o surgimento de novas necessidades, sendo a compra do arroz o exemplo mais notável, haja vista a grande produção desse artigo na Ilha de São José.

Para a maioria dos camponeses, o fator responsável pela baixa produtividade do arroz é devido as características físicas do ambiente. Um entrevistado diz:

\begin{abstract}
“Arroz eu não planto, porque arroz aqui é muito difícil para produzir em roça pequena. Por exemplo, se eu vou fazer uma roça para o consumo próprio, o preparo do solo precisa ser muito bem feito... Da hora que você planta você tem que passar para dentro! Você tem que passar para dentro até que ele atinja uns $20 \mathrm{~cm}$ de altura, por que se não o Cariri [pássaro] vai lá e arranca; ele vai lá encima da cova e puxa a semente! Depois, quando ele começa a botar os cachos você precisa está lá, até o dia de você panhar[colher]. Aqui ajunta milhares de Cariri! (Gerdean Carvalho, 40 anos).
\end{abstract}

Outro fator determinante para a não produção do arroz na proximidade do assentamento a Araguaína, onde os preços desse produto são acessíveis. Um camponês afirma que: "No início, teve até uma produção [de arroz], mas quando a gente parou para analisar o preço que estava lá no supermercado, e comparando com as dificuldades do plantio, vimos que não compensava”.

O arroz é um gênero de primeira necessidade, devendo estar dia após dia na mesa do trabalhador camponês. No assentamento Mirindiba, esse cereal deixa de ser produto imediato do trabalho das famílias. Agora, torna-se indispensável a comercialização de outros artigos para que o dinheiro seja adquirido, e a compra desse produto efetivada. Os excedentes da pequena manufatura, do leite, do milho, da mandioca e das criações são comercializados, não apenas para comprar o supérfluo, mas também produtos básicos da dieta camponesa. Nesse hall se inserem outros artigos, que se tornaram essenciais devido às deficiências do novo território, a saber,o adubo, o veneno, os gastos com energia elétrica, e, em alguns casos, até mesmo a carne e o feijão. A fala de um camponês retrata bem essa realidade:

"Agora hoje aqui pode se dizer que a gente compra quase tudo. O que a gente não compra é a farinha, por que nós a produzimos aqui, mas até o arroz vem de lá... Aqui as compras no supermercado tem mais valor... Lá na 
ilha a gente só comprava as coisas auxiliares, porque lá nós tínhamos o arroz, tinha o feijão..." (Júlio da Silva, 61 anos).

A mandioca assume a vanguarda da produção, sendo bastante aceita no mercado de Araguaína, além de constituir a matéria-prima de outras mercadorias. Depois de ultrapassado os limites do consumo doméstico, esse artigo passa a ser comercializada pelos camponeses. A manufatura da mandioca, por outro lado, consiste, principalmente, na produção de farinha, alicerçada no regime de mutirão. Nesse sistema de cooperação, a casa de fazer farinha (Imagem 10) é utilizada de forma coletiva por membros de duas ou mais famílias. A matériaprima, mandioca, se origina da lavoura daqueles que estão envolvidos. Ao término do processo ocorre a divisão da produção.

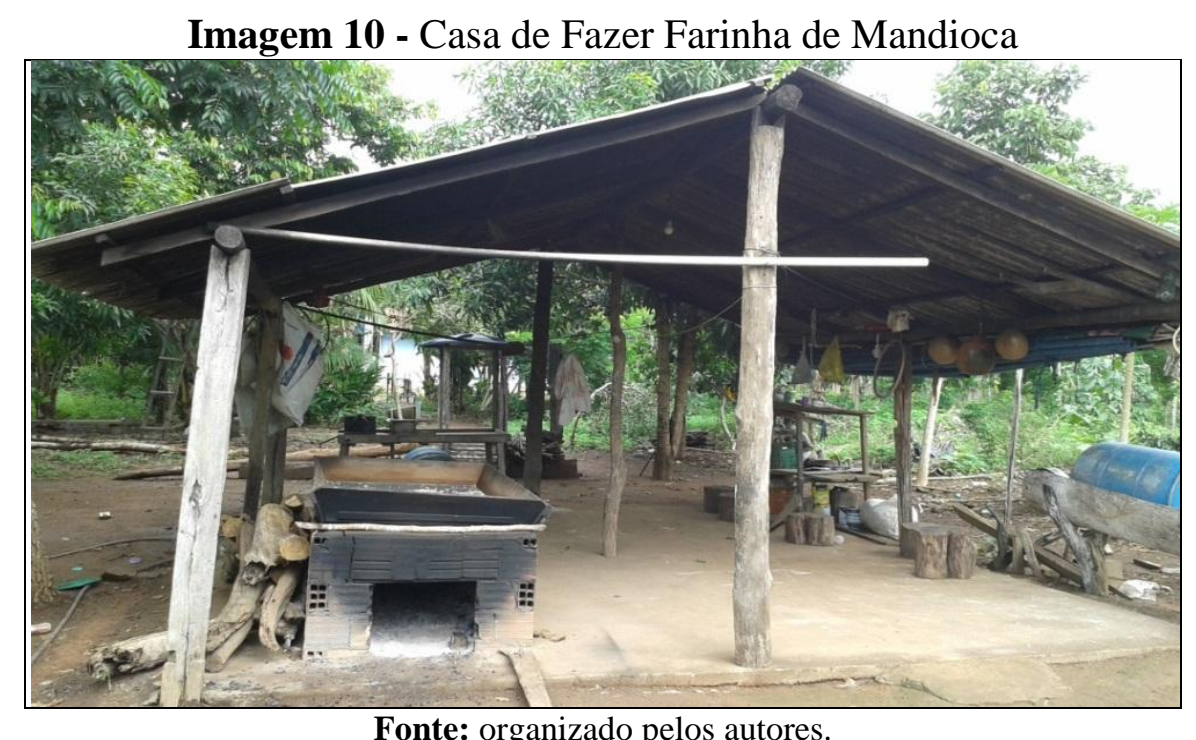

Mesmo nessas condições a farinha não é produzida em grande escala, ao ponto de se tornar uma mercadoria. Todos os camponeses são unânimes em afirmar que o seu valor de mercado não condiz com o dispêndio de trabalho nela cristalizado. O problema salta então para a concorrência, já que a farinha se trata de um produto manufaturado. Ora, na grande indústria, a produtividade do trabalho é bem maior do que a registrada na pequena manufatura camponesa. O uso da maquinaria, por exemplo,faz com que os custos de produção sejam mais baixos nesse setor. De modo que "A concorrência força o produtor a vender o produto de duas horas tão barato como o de uma hora" (MARX, 2009, p. 79); assim, a competição com a indústria se torna impraticável, tornando a farinha um produto restrito às necessidades da própria família.

Hoje, mesmo estando próximos a um importante centro comercial como Araguaína, os camponeses ainda encontram dificuldades no escoamento da produção. Não existem meios de 
transporte que viabilizem a dinâmica do assentamento. Tal deficiência concorre para o aparecimento da figura do atravessador. Ele se torna então o responsável pela intermediação entre a produção camponesa e o consumidor final, ou mesmo com os capitalistas industriais e comerciais da cidade. De qualquer forma, esse ator se apropria dos rendimentos que poderiam ser auferidos pela unidade produtiva, caso a comercialização ocorresse de forma direta, já que os produtos podem ser vendidos abaixo de seus custos a esse intermediário. Por isso José de Souza Martins assevera que o camponês enquanto produtor de "excedentes agrícolas fora de esquemas e de relações capitalistas de produção, pode vender os seus produtos por qualquer preço, o que beneficia os intermediários que acumulam capital às suas custas, e contribui para o abastecimento de imensas regiões" (MARTINS, 1995, p. 116). O leite, por exemplo, é um dos produtos mais visados pelos atravessadores em Araguaína (Imagem 11); nesse caso, o intermediário faz a transição entre os produtores diretos e os laticínios da cidade.

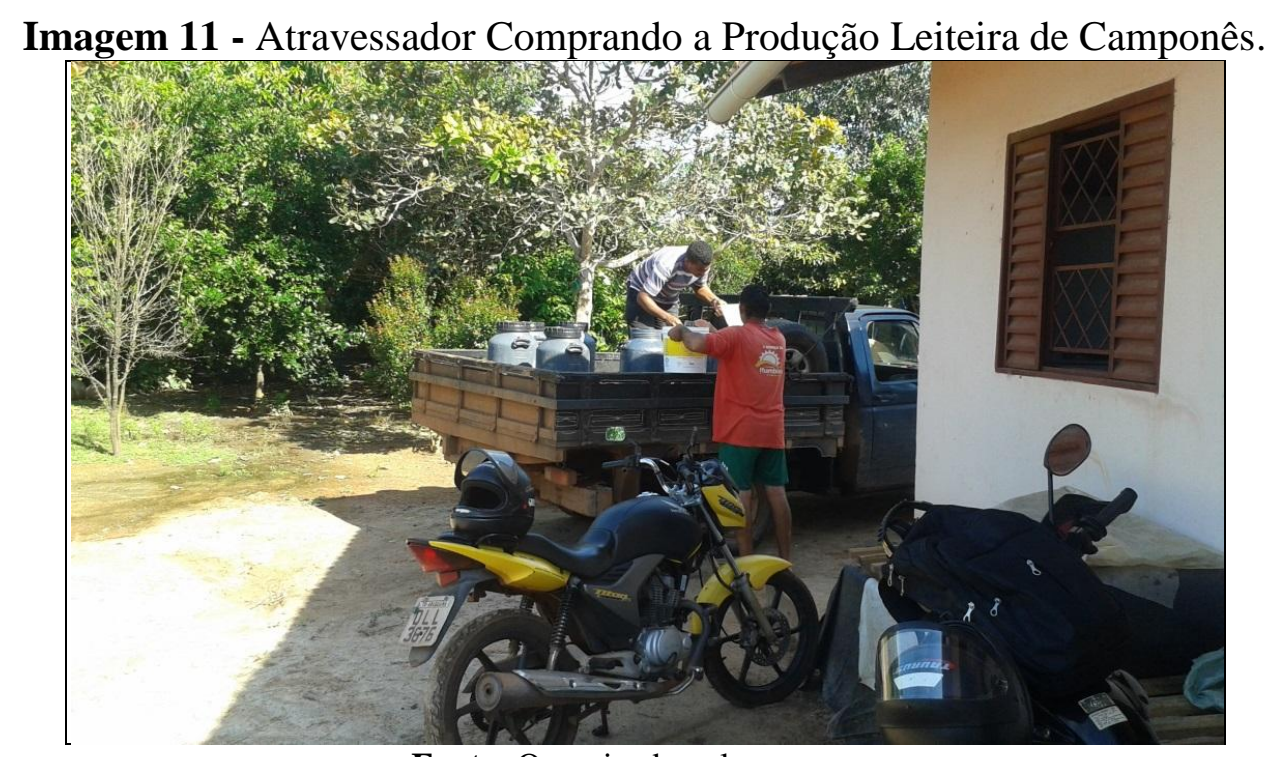

Fonte: Organizado pelos autores.

A indústria em si, muitas das vezes por questões estratégicas, não quer se indispor com o monopólio que representa as grandes propriedades; por isso, se atrela à produção camponesa; "Trata-se, isto sim, de um processo incrível de desenvolvimento da própria produção camponesa pelo capital para, inicialmente, fazer frente à pressão dos preços do arrendamento da terra" (OLIVEIRA, 1987, p. 68). De certa forma, o campesinato se torna gradualmente um produtor de mercadorias, dentro de certas especificidades; e essa sua condição "é produto do próprio capitalismo", entretanto, nem por isso deve ser visto "como um assalariado disfarçado ou um trabalhador a domicílio" (OLIVEIRA, 1987, p. 68). O importante, a saber, é que o camponês se mantém como um produtor não-capitalista, sendo o 
trabalho de base familiar e a posse dos meios de produção as características principais da economia campesina.

O que acontece, na verdade, é o desenvolvimento do capital especificamente na esfera da circulação, ocasionando o domínio da produção.

Nesse caso, quando submete o camponês aos seus ditames, está sujeitando a renda da terra ao capital. Está convertendo o trabalho excedente do camponês e sua família em renda capitalizada. Está se apropriando da renda sem ser o proprietário da terra. Está produzindo o capital pela via não especificamente capitalista (OLIVEIRA, 1987, p. 53).

Conclui-se que:

A continuação e o funcionamento da economia familiar camponesa resultam das relações dialéticas que a unidade familiar estabelece com a economia e a sociedade nacional e mundial com o objetivo de utilizar os recursos produtivos de que dispõe, sendo o principal deles o trabalho. Nesse processo, a economia familiar camponesa se diferencia da economia capitalista ao mesmo tempo em que faz parte dela (MARQUES, 2008a, p. 71).

Como tentativa de luta contra essas amarras do capital, o campesinato remanescente da Ilha de São José se organizou através da criação de uma associação. O galpão da associação (Imagem 12) é utilizado frequentemente para as reuniões dos assentados, e também para os encontros com os representantes do CESTE. Após os primeiros anos de baixa produtividade no assentamento, a associação teve um papel crucial na vida dos camponeses, pois de forma coletiva as famílias firmaram um convênio com a Companhia Nacional de Abastecimento (CONAB), ganhando o direito de participar como fornecedores do Programa de Aquisição de Alimentos (PAA), administrado pelo órgão.

Imagem 12: Sede da Associação dos Camponeses do Assentamento Mirindiba.

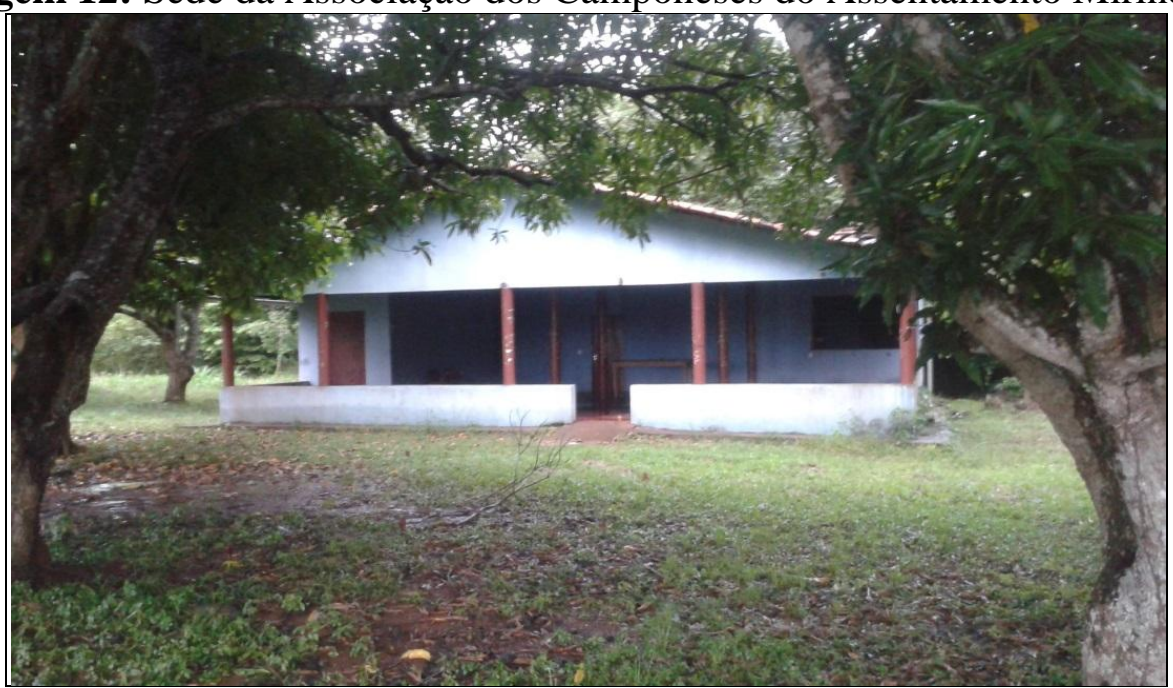

Fonte: Organizado pelos autores. 
O programa consistia na comprada produção camponesa por esse órgão da administração federal. Após o aceite do projeto havia a procura por entidades parceiras, que viriam a receber as mercadorias, geralmente organizações de cunho social. Seu Júlio da Silva, na época à frente da associação, afirma que: "Nós tínhamos 4 parceiros em Araguaína: a $\mathrm{APAE}^{4}, \mathrm{FUNAMC}^{5}$, Comunidade Vida Nova ${ }^{6}$, e tinha a Cuidar ${ }^{7}$ ". O dinheiro do convênio era depositado na conta da associação após a última remessa de mercadorias, e logo em seguida repassado a cada um dos participantes. Ao todo foram executados 2 projetos, cada um com duração média de 1 ano e meio.O primeiro teve um orçamento na faixa de R \$ 38.000 mil; já no segundo, o orçamento mais que dobrou, saltando para algo em torno de $\mathrm{R} \$ 93.000$ mil. De início,apenas8 famílias participaram, número que saltou para 14 unidades produtivas no segundo projeto.De acordo com as informações colhidas em campo, a última entrega de alimentos feita pelos assentados foi no ano de 2016. Segundo o senhor Júlio da Silva, fornecia-se de tudo:

Aqui ia abóbora, banana, a massa de mandioca, feijão, as coisas que a gente planta na horta, o cheiro-verde, este era o melhor de preço! Todo tipo de coisa! Mas o foco principal toda vida foi a mandioca... Ia a farinha seca, a farinha puba, ia até o polvilho, o milho verde... Tinha mês aí que o cara ficava bom de bolso [endinheirado] (Júlio da Silva, 61 anos).

O dinheiro recebido também era utilizado de modo comunitário, principalmente na aragem do solo. Todas as propriedades foram beneficiadas a custo mais baixo, fazendo com que o capital disponível rendesse de forma mais proveitosa. Atualmente, os camponeses não desenvolvem qualquer projeto no assentamento, em grande parte como consequência do desânimo criado pela falta de títulos definitivos das propriedades.

\section{A luta pela propriedade jurídica da terra}

Os mesmos camponeses que produzem e reproduzem o seu modo de vida no assentamento Mirindiba sofrem ainda as consequências do descaso por parte do CESTE, mesmo transpassada uma década de residência na nova morada. A propriedade da terra ainda

\footnotetext{
${ }^{4}$ Associação de Pais e amigos dos Excepcionais (APAE).

${ }^{5}$ Fundação de Atividade Municipal Comunitária (FUNAMC).

${ }^{6}$ Organização Cristã Protestante que realiza o tratamento de dependentes químicos em Araguaína.

${ }^{7}$ Instituição de acolhimento a dependentes químicos.
} 
não está efetivada em termos jurídicos, pois a velha promessa de que os títulos definitivos seriam entregues após 5 anos nãose concretizou. Essa é mais uma etapa da luta travada por essas famílias. Forma-se um contraste de realidades, já que na Ilha de São José a maioria dos camponeses tinha as suas terras devidamente documentadas. Muitos temem ser expulsos de seus lotes, assim como aconteceu na ilha. A última promessa foi de que os documentos seriam entregues até junho de 2018, fato que não se cumpriu. Isso demonstra o aproveitamento dos empreendedores diante da falta de fiscalização, ou melhor, diante da omissão do Estado.

O compromisso de 2018 necessitava de uma contra partida por parte dos camponeses, já que os mesmos deveriam abrir mão de suas causas indenizatórias na justiça. Esse conflito jurídico representa a luta dos camponeses pelos seus direitos, sobretudo pelo fato de o consórcio empreendedor não ter levado em consideração as benfeitorias existentes nas antigas propriedades. Para os camponeses, a parcela de terra do Mirindiba representa apenas o topográfico, ou seja, mera extensão em metros quadrados, equivalente à propriedade da Ilha de São José. Assim, partindo do pressuposto de que o assentamento Mirindiba fora entregue sem nenhum atributo, ou melhor, sem nenhuma quantidade significativa de trabalho anterior cristalizado, pode-se dizer que os camponeses lutam na justiça pela restituição daquilo que eles não puderam trazer para o novo território: os currais, as cercas, galinheiros, chiqueiros, casas, pomares, solos beneficiados etc.

O campesinato se vê refém de uma chantagem social, já que para receberem os títulos, os camponeses precisam abrir mão de um direito fundamental, que é a indenização. "Eles chegaram aqui um dia", relata um camponês a respeito dos representantes do CESTE, "E a gente perguntou qual era a expectativa dos documentos. Eles disseram: 'se acabar as causas na justiça os títulos saem"”. Quase todos os assentados lutam pelas indenizações, fazendo com que os empreendedores se utilizem desse pretexto para intimidar as famílias. O terrorismo do CESTE sobre essa questão é narrado na seguinte fala:

"Sobre os títulos dessa terra aqui... Eles [Consórcio] vivem só querendo matar nós do coração! Eu já digo é logo desse jeito, porque teve gente que na última reunião passou mal. Eles disseram que já tinha o documento com a desapropriação de certos produtores daqui de dentro! Eles disseram que o seu João, que mexe com a máquina, já tinha o documento de desapropriação no seu nome, por conta das causas na justiça." (Gerdean Carvalho, 40 anos).

Após esse episódio, verificou-se que a história não passava de uma farsa. Na verdade, esta é mais uma estratégia para que os camponeses abram mão de seus direitos e, dessa forma, o CESTE venha a poupar gastos. Essa condição, por outro lado, faz com que muitas famílias 
se sintam inibidas de fazer qualquer benfeitoria mais expressiva em suas terras, pois, segundo eles, o futuro é incerto. Alguns camponeses alegam que a ausência dos títulos tem feito com que estes percam tempo, já que a posse da documentação facilitaria o acesso ao crédito bancário que, de acordo com os relatos, desenvolveria as forças produtivas já existentes. Outros sujeitos já expressam um franco desânimo, afirmando que abririam mão das causas na justiça pelo documento de sua propriedade. A lentidão do judiciário também é um fator determinante, sendo mais uma arma para que as grandes empresas continuem a agir em desfavor das comunidades tradicionais atingidas por empreendimentos hidroenergéticos. Por isso, alguns entrevistados falam até mesmo em vender as suas parcelas.

\section{Considerações finais}

Em virtude do que foi mencionado, ficou claro que a marcha incessante de lutados camponeses do assentamento Mirindiba se dá em várias frentes: contra o capital que se apropria da produção por meio da circulação; contra a instância jurídica que está sempre em consonância com os interesses da burguesia; contra as condições adversas de produção e a falta de recursos; contra os grandes proprietários da vizinhança que os marginalizam e também contra a desmotivação causada pela ausência de títulos definitivos de propriedade. Portanto, o campesinato luta contra tudo aquilo que visa dificultar ou mesmo impedir a continuidade do seu modo de vida no novo território.

A expulsão dos camponeses da Ilha de São José e a sua chegada até o assentamento Mirindiba, representa o choque de dois mundos em um só. A sociedade capitalista avançada desconsidera toda e qualquer forma de organização que não seja a sua. A luta desses camponeses dá uma real dimensão do quanto a expansão do capitalismo precisa ser rediscutida. O lema do "progresso" carrega em si uma ideologia cega e descomprometida com as comunidades tradicionais. Pela modernização tudo se pode, essa é a bandeira do Estado e das grandes empresas. A expulsão desses camponeses traz à tona as contradições do modo de produção burguês. Os atores hegemônicos tentam passar a imagem de que a sua territorialização se dá sobre regiões inabitadas. Mas, a realidade tem mostrado uma versão diferente da ficção idealizada pelos empreendedores. A oposição, firmada até as últimas consequências, por parte do grupo de camponeses formadores do assentamento Mirindiba é prova de que o antagonismo existente entre o consórcio e os atingidos não pode ser reconciliado tão facilmente. 
O assentamento Mirindiba é agora o espaço de reprodução da vida imediata do campesinato. Esse novo território não representa as antigas condições de produção da Ilha de São José. O mercado se tornou a peça principal na reprodução das unidades produtivas, e não mais um vínculo acessório. A necessidade de dinheiro agora é corriqueira, e a produção se especializa à medida que os atributos físicos do lugar não concorrem para uma variedade produtiva eficiente. Essa situação é o reflexo do descaso social, político e econômico pelo qual tem passado não só os camponeses do assentamento Mirindiba, mas todo um conjunto populacional atingido por usinas hidrelétricas no Brasil ao longo do tempo. Sejam eles camponeses, indígenas, pescadores ou quilombolas.

A luta pela continuidade do modo de vida no assentamento não é tarefa fácil. A economia de excedentes não é mais a mesma, já que a produção de alimentos essenciais se tornou inviável nas novas terras. Surge uma especialização baseada no plantio da mandioca, que atrelada à figura do atravessador faz com que o trabalho do campesinato seja subvalorizado. Antes, o essencial era produzido pelas próprias unidades produtivas, agora, esse quadro se modifica substancialmente. $\mathrm{O}$ arroz, o feijão, a gordura e as frutas, por exemplo, que são artigos básicos da alimentação camponesa, outrora produzidos diretamente pelas famílias, não se encontram mais em tais condições. As dificuldades de escoamento das mercadorias somadas à baixa produtividade do solo fazem com que a produção tome um destino diferente do da ilha. A cesta de produtos excedentes se tornou menos diversificada. $\mathrm{O}$ atravessador, de certa forma, determina o que deve ser produzido em escala maior, já que ele é o responsável pela integração camponês-mercado.

As novas necessidades se dão como uma tormenta na vida dos camponeses. Os altos custos da energia elétrica e a necessidade de correção do solo são de longe os exemplos mais emblemáticos. Soma-se a isso a falta de apoio técnico e de políticas públicas que viabilizem o manejo e o escoamento da produção de forma justa. Esses desafios batem todos os dias à porta das unidades produtivas do assentamento Mirindiba. A concorrência da indústria impede qualquer desenvolvimento sólido da produção de artigos manufaturados. A instância jurídica cumpre o seu papel parcial em favor dos empreendedores, e é por meio da morosidade dos tribunais que as causas indenizatórias não saem do lugar.Portanto, a luta pela continuidade do modo de vida camponês se assenta em todas essas problemáticas, e são nessas condições que as unidades produtivas vêm reproduzindo a sua economia. 


\section{Referências}

ALTHUSSER, Louis. Ideologia e Aparelhos Ideológicos do Estado. Tradução: Joaquim de Moura Ramos. Lisboa: Editorial Presença, 1970.

CAMPOS, Rui Ribeiro de. Tese, Antítese, Síntese e Tese. Boletim Paulista de Geografia, São Paulo, n. 77, p. 79-98, 2001.

CARNEIRO, Patrício. A Unidade de Produção Familiar e os Enfoques Teóricos Clássicos. CAMPO-TERRITÓRIO: revista de geografia agrária, v 4, n 8, p. 52-66, agosto de 2009.

DOLLFUS, Olivier. O Espaço Geográfico. Tradução:Heloysa de Lima Dantas. São Paulo: Bertrand Brasil, 1991.

ENGELS, Friedrich. Introdução de F. Engels para a Edição de 1891. In: MARX, Karl. Trabalho Assalariado e Capital \& Salário, Preço e Lucro. São Paulo: Expressão Popular, 2010.

FABRINI, João Edimilson. Movimentos Sociais no Campo e Outras Resistências Camponesas. In: PAULINO, E. T.; FABRINI, J. E. (Orgs.). Campesinato e Território em Disputa. São Paulo: Expressão Popular, 2008.

HARVEY, David. O Espaço como Palavra-Chave. Tradução: Letícia Gianella. Revista em Pauta, Rio de Janeiro, n 35, v 13, p. 126-152, 2015.

IANNI, Octávio. A Utopia Camponesa (1986). In: WELCH, Clifford Andrew et al (Orgs.). Camponeses Brasileiros: leituras e interpretações clássicas.V.1. São Paulo: Editora UNESP; Brasília: Núcleo de Estudos Agrários e Desenvolvimento Rural, 2009.

MARINHO, Claudiney de Freitas; LIRA, Elizeu Ribeiro. O Bispo Dom Pedro Casaldáliga e a Opção pelos Pobres da Terra na Região do Araguaia. In: LIRA, Elizeu Ribeiro (org.). Geografia Agrária do Tocantins: campesinato, latifúndio e conflito. Goiânia: Kelps, 2018.

MARQUES, M. I. M. Agricultura e Campesinato no Mundo e no Brasil: um renovado desafio à reflexão teórica. In: PAULINO, E. T.; FABRINI, J. E. (Orgs.). Campesinato e Território em Disputa. São Paulo: Expressão Popular, 2008a.

A Atualidade do Uso do Conceito de Camponês. Revista NERA, Presidente Prudente, ano 11, n. 12, p. 57-67, janeiro/julho 2008b.

MARTINS, José de Souza. Os Camponeses e a Política Pública no Brasil: as lutas sociais no campo e seu lugar no processo político. Petrópolis: Vozes, 1995.

2016.

Fronteira: a degradação do Outro nos confins do humano. São Paulo: Contexto,

MARX, Karl. Manuscritos Econômico-Filosóficos. Tradução: Jesus Ranieri. São Paulo: Boitempo Editorial, 2008. 
. Miséria da Filosofia: resposta à Filosofia da miséria, do Sr. Proudhon. Tradução: José Paulo Netto. São Paulo: Expressão Popular, 2009.

O Capital: crítica da economia política: livro I: o processo de produção do capital. Tradução: Rubens Enderle. São Paulo: Boitempo, 2013.

OLIVEIRA, Ariovaldo Umbelino de. Agricultura e Indústria no Brasil. Boletim Paulista de Geografia, São Paulo, n 58, p. 5-64, 1981.

Princípios).

Modo de Produção Capitalista e Agricultura. São Paulo: Ática, 1987. (Série

. A Agricultura Camponesa no Brasil. São Paulo: Contexto, 2001a. (Caminhos da Geografia).

A Longa Marcha do Campesinato Brasileiro: movimentos sociais, conflitos e reforma agrária. Estudos Avançados, São Paulo, 15 (43), p. 185-206, 2001 b.

Agricultura Brasileira: transformações recentes. In: ROSS, Jurandyr (Org.). Geografia do Brasil. São Paulo: Editora da Universidade de São Paulo, 2005. (Didática; 3).

. Modo de Produção Capitalista, Agricultura e Reforma Agrária. São Paulo: Labur Edições, $2007 . \quad$ Disponível em<http://www.geografia.fflch.usp.br/graduacao/apoio/Apoio/Apoio_Valeria/Pdf/Livro_ari.p df>. Acesso em04 de fevereiro, 2016.

PAULINO, Eliane Tomiasi. Por uma Geografia dos Camponeses. São Paulo: Editora UNESP, 2006.

SANTOS, Alisson Almeida dos; SIEBEN, Airton. Hidreletricidade e Des-re-territorialização: uma análise a partir no reassentamento Mirindiba localizado no município de Araguaína-TO. Revista Tocantinense de Geografia, Araguaína, ano 3, n. 01, p. 1-10, jan-jul, 2014.

SHANIN, Teodor. A Definição de Camponês: conceituação e desconceituação - o velho e o novo em uma discussão marxista. Revista NERA, Presidente Prudente, ano 8, n 7, p. 1-21, jul./dez, 2005.

SIEBEN, Airton. Estado e Política Energética: a desterritorialização da comunidade rural de Palmatuba em Babaçulândia (TO) pela Usina Hidrelétrica Estreito. Universidade Federal de Uberlândia, 2012, 204f. (tese de Doutorado em Geografia)

SORRE, Max. A Geografia Humana (Introdução). GEOgraphia, Niterói, ano V, n. 10, p. 137-143, 2003. 